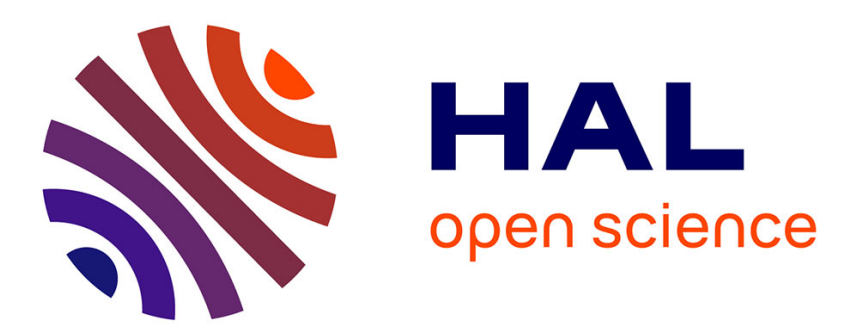

\title{
Interactions between hydrated cement paste and organic acids: Thermodynamic data and speciation modeling
} Laurent de Windt, Alexandra Bertron, S. Larreur-Cayol, Gilles Escadeillas

\section{To cite this version:}

Laurent de Windt, Alexandra Bertron, S. Larreur-Cayol, Gilles Escadeillas. Interactions between hydrated cement paste and organic acids: Thermodynamic data and speciation modeling. Cement and Concrete Research, 2015, 69, pp.25-36. hal-01108814

\section{HAL Id: hal-01108814 \\ https: / hal-mines-paristech.archives-ouvertes.fr/hal-01108814}

Submitted on 3 Nov 2015

HAL is a multi-disciplinary open access archive for the deposit and dissemination of scientific research documents, whether they are published or not. The documents may come from teaching and research institutions in France or abroad, or from public or private research centers.
L'archive ouverte pluridisciplinaire HAL, est destinée au dépôt et à la diffusion de documents scientifiques de niveau recherche, publiés ou non, émanant des établissements d'enseignement et de recherche français ou étrangers, des laboratoires publics ou privés. 


\title{
Interactions between hydrated cement paste and organic acids: Thermodynamic data and speciation modelling
}

Laurent De Windt $^{(1)}$, Alexandra Bertron ${ }^{(2)}$, Steeves Larreur-Cayol ${ }^{(2)}$, Gilles Escadeillas ${ }^{(2)}$

(1) MINES ParisTech, PSL Research University, Centre de Géosciences, 35 Rue St-Honoré, 77305 Fontainebleau Cedex (France).

(2) University of Toulouse, UPS/INSA/LMDC, 135 Av. de Rangueil, 31077 Toulouse Cedex 04 (France).

*Corresponding author, Email= laurent.dewindt@mines-paristech.fr ;

Tel $=+33-1-64.69 .49 .42 ;$ Fax $=+33-1-64.69 .47 .13$

\begin{abstract}
.
Interactions of short-chain organic acids with hydrated cement phases affect structure durability in the agro-food and nuclear waste industries but can also be used to modify cement properties. Most previous studies have been experimental, performed at fixed concentrations and $\mathrm{pH}$, without quantitatively discriminating among polyacidity effects, or complexation and salt precipitation processes. This paper addresses such issues by thermodynamic equilibrium calculations for acetic, citric, oxalic, succinic acids and a simplified hydrated CEM-I. The thermodynamic constants collected from the literature allow the speciation to be modelled over a wide range of $\mathrm{pH}$ and concentrations. Citric and oxalic had a stronger chelating effect than acetic acid, while succinic acid was intermediate. Similarly, $\mathrm{Ca}$-citrate and $\mathrm{Ca}$-oxalate salts were more insoluble than $\mathrm{Ca}$-acetate and $\mathrm{Ca}$-succinate salts. Regarding aluminium complexation, hydroxyls, sulphates, and acid competition was highlighted. The exploration of acid mixtures showed the preponderant effect of oxalate and citrate over acetate and succinate.
\end{abstract}

Keywords: A. Reaction; B. Degradation; C. Organic Acids; D. Radioactive Waste; E. Agricultural effluents. 


\section{Introduction}

Concrete can be exposed to organic acids in various contexts. In the agricultural and agro-food industries, concrete facilities dedicated to the production, collection, storage and/or treatment of effluents (manure, silage juices, dairy effluents, winery waste waters, etc.) are subjected to severe chemical and biological attack $[1,2]$. The waste waters contain a wide range of short-chain organic acids (acetic, lactic, tartaric, oxalic, succinic, etc. [3]), mostly coming from the microbial activity naturally occurring in such media. Very different types of structures can be degraded (storage silos, cowsheds, milking rooms, collecting systems, biogas silos...), sometimes with very high kinetics [2]. In deep repositories for type-B long-lived, intermediate level nuclear wastes (LL-ILW), bitumen is used to stabilize the wastes. After closure and water re-saturation of the cell, bituminous wastes are expected to release various organic compounds, including organic acids such as acetic, formic and oxalic acids, as a result of leaching and radiolysis [4 - 7]. It has been shown that strong interactions can occur between these organic acids and the concrete of the waste cell [8] thus modifying the bio-chemical conditions in the vicinity of the bitumen-concrete interface [8,9]. This could have a direct influence on safety [10]. Also, in the nuclear industry, when cellulose materials are immobilized with other LL-ILW in cement matrices, the cellulose may degrade under these highly alkaline conditions, mainly into isosaccharinic acid but also into acetic and formic acids [11]. These acids can then react with the cementitious matrix.

Considering the above mentioned unwanted effects, attempts have been made to take advantage of the particular characteristics of some of these organic acids and their salts so as to improve some properties of the fresh or hardened cement paste matrix. In fresh cement paste, citric and oxalic acids have been exploited to modify setting time [12]. The protective action of oxalic acid on the hardened cement matrix has been explored either by incorporating oxalic acid into the fresh mix [13] or by using it as an external treatment of the hardened matrix [14].

The mechanisms of the interactions between organic acids and cement paste are thus of interest. The physicochemical mechanisms of such acid attack have already been investigated, mostly experimentally. Two groups of acids have been identified: (i) acids with soluble salts, such as acetic, butyric, lactic or propionic acids and (ii) acids with slightly soluble to insoluble salts, including malic, oxalic, succinic and tartaric acids [3], [15]. For the first group, alteration mechanisms appear similar to those observed with strong acids such as nitric or hydrochloric acids $[3,16,17]$. For the second group, the physical and chemical properties of the acid salts (solubility, molar volume, affinity of salt for the cement matrix) seemed to influence the intensity of alteration and a correlation was observed between the molar volumes of the salts and the intensity of alteration of the matrix [18].

However, the influence of some phenomena or properties is difficult to demonstrate experimentally. For example, the formation of complexes involving metal cations and conjugate bases of the different acids can increase the apparent solubility of cementitious phases. Also, even though it is suspected, no real evidence of the role of polyacidity (e.g. citric and succinic acids) on the aggressiveness of the acid has been found so far [3,15, 18]. Calcium is generally considered when studying the acid-cement interactions but the stability of aluminium should also be better investigated since most binders renowned as more stable than Portland cement in acidic environments are aluminium-rich materials (cement with slag, metakaolin-bearing binders, calcium aluminate cements). Finally, experimental campaigns are generally conducted with no variation of the acid concentrations or the $\mathrm{pH}$. (Although $\mathrm{pH} 4$ is the most widely used, $\mathrm{pH}$ values of 1,3 or 6 have also been investigated [13, 18-21].

Modelling is a relevant, complementary way to address all these issues. A first model of the degradation of cement pastes by biogenic acids (acetic, butyric, lactic and oxalic) produced by the metabolism of fungi has recently been proposed [22]. This reactive transport modelling indicated that organic acids strongly accelerated hydrate dissolution by acidic hydrolysis while their complexation had an effect on the stability of the aluminosilicate phase that remained after the full decalcification of the cement hydrates. However, efforts focused on the link between mineral alteration and diffusion and less on the detailed chemical interactions between cementitious cations and organic acids. In particular, applying thermodynamics to cement science has proved 
to be a very valuable approach and has been in use for many decades now [23]. In particular, thermodynamic modelling efficiently supports the assessment of the durability of a cement paste in organic environments.

The purpose of the present paper is to model such chemical interactions, to allow for species occurrence and concentration over a wide range of $\mathrm{pH}$, and to better capture the interdependence between aqueous complexation, precipitation of salts and cement phase stability. Four organic acids having distinct chemical properties were studied, i.e. acetic, citric, oxalic and succinic acids. A first, essential, step was to obtain thermodynamic constants concerning their polyacidity, their organometallic complexes of $\mathrm{Al}$ and $\mathrm{Ca}$, and their $\mathrm{Ca}$-salt solubility as the relevance of speciation modelling depends directly on the completeness and quality of the thermodynamic data [23]. Little attention has been paid to organic acid data in cement science, so acid titration was modelled and simplified stability diagrams were drawn up in a second stage. Finally, speciation modelling was analysed for pure acid solutions and for a mixture of the four acids.

\section{Modelling approach and thermodynamic data}

\subsection{Thermodynamic equilibrium calculations}

The geochemical code CHESS/HYTEC [24] takes account of all the chemical reactions in an aqueous solution. In the present case, the relevant reactions were mainly i) acid/base reactions and ion complexation in solution and ii) dissolution and precipitation of solid phases. The thermodynamic equilibrium is dependent on a set of mass balance equations, characterized by formation constants $K_{i}$, which are functions of temperature (equation 1):

$$
n_{A} A+n_{B} B \leftrightarrow n_{C} C+n_{D} D ; K_{i}(T)=\frac{(C)^{n_{C}}(D)^{n_{D}}}{(A)^{n_{A}}(B)^{n_{B}}}
$$

The equilibrium state is solved numerically according to the basis component approach and an improved Newton-Raphson scheme. The empirical formula of the truncated Davies model derived from the Debye-Huckel model of activity corrections of dissolved ions was used for this study. The activity coefficient $\gamma_{i}$ of a given ion $i$ writes as

$$
\log \gamma_{i}=-A Z_{i}^{2}\left(\frac{\sqrt{I}}{1+\sqrt{I}}\right)-0.3 I
$$

where the empirical parameter $A$ is about 0.5 between $5^{\circ} \mathrm{C}$ and $30^{\circ} \mathrm{C}, Z_{i}$ is the ion charge and $I$ is the ionic strength. There is no activity correction for dissolved neutral species. The model is applicable for low to moderately mineralized solutions (i.e. ionic strength $I \leq 0.5 \mathrm{~mol} / \mathrm{kg}$ ).

CHESS was used to draw simplified stability and phase diagrams on acid activity $-\mathrm{pH}$ axes on the one hand, and full thermodynamic speciation graphs of species concentrations versus $\mathrm{pH}$ on the other hand. The full chemical interactions between species, and also activity corrections, were taken into account in the latter case. A constant temperature of $25^{\circ} \mathrm{C}$ was used for all calculations.

\subsection{Thermodynamic data}

Four organic acids were considered: acetic, citric, oxalic and succinic acids. Experimental campaigns have pointed out that these acids differ greatly in their aggressiveness toward the cement matrix in terms of alteration kinetics, evaluated through altered layer thicknesses and mass changes $[3,13,17]$. A summary of the main alteration phenomena observed experimentally on cement matrices exposed to these organic acids (acetic, succinic, citric, and oxalic acids) alone or in mixtures are provided in Table 1. The relative aggressiveness - in terms of altered (layer depths) kinetics - of the acid solutions is also given. The acids in question are commonly found in various organic leachates and effluents $[3-7,11]$. They are mono- or poly-acids, which means that they have one or more carboxylic functional groups (R-COOH): one for acetic acid, two for oxalic and succinic acids, and three for citric acid. Calcium acetate salt is highly soluble in water 
at room temperature, succinate and citrate Ca-salts are slightly soluble, and oxalate salts are clearly insoluble [3].

The polyacidity of these organic acids, their dissociation constants (pKa), the formation constants of the organometallic complexes of aluminium and calcium (Table 2), and the formation constants of the calcium organic salts (related to their solubility products) were considered in the calculations (Table 2). The MINTEQ 2.20 database [25] was used for most of the formation constants of species encountered in this study but was also enriched with relevant thermodynamic data extracted from the EQ3/6 [26], Thermochimie [27] and NEA [28] databases. A few formation constants of Ca-salts were directly fitted with CHESS from empirical solubility data tabulated in handbooks and in the literature [25, $29-37]$. Some representative solid phases of hydrated cement were used in the calculations (Table 3), i.e. C-S-H 0.8, C-S-H 1.2, C-S-H 1.6, portlandite, ettringite and gibbsite from the Thermoddem database [38]. This discrete sequence of the three $\mathrm{C}-\mathrm{S}-\mathrm{H}$ was found to be relevant for modelling pozzolanic reactions in batch tests over a wide $\mathrm{pH}$ range [39].

A number of features of the selected dataset are worth mentioning.

- $\mathrm{Al}$ and $\mathrm{Ca}$ cations are complexed by the conjugated bases (anions of the acids). The acid and conjugated bases were left in literal form to facilitate the recognition of the different species, i.e. acetate for $\mathrm{C}_{2} \mathrm{H}_{3} \mathrm{O}_{2}^{-}$, citrate for $\mathrm{C}_{6} \mathrm{H}_{5} \mathrm{O}_{7}^{3-}$, oxalate for $\mathrm{C}_{2} \mathrm{O}_{4}{ }^{2-}$ and succinate for $\mathrm{C}_{4} \mathrm{H}_{4} \mathrm{O}_{4}{ }^{2-}$.

- Most organometallic complexes are binary metal-carboxyl complexes, although some ternary metal-hydroxyl-carboxyl complexes (of $\mathrm{AlOH}^{2+}$ and $\mathrm{Al}(\mathrm{OH})_{2}{ }^{+}$ions) have also been measured experimentally. The modelling of the full complexity of speciation in cement pore waters could be biased by the lack of experimental studies on ternary complexes.

- Succinic acid presents the most reduced set of species. For instance, there are no di- or tri-carboxyl complexes.

- Data were only available for all the calcium salts in the literature but not for the aluminium salts. Therefore, caution should be exercised when analysing the solubility of aluminium in carboxylic acid solutions from the present speciation modelling. Nevertheless, it should be noted that only calcium salts were identified in experimental campaigns intended to characterize the mineralogical changes in cement pastes made of ordinary binders (CEM I, CEM III, CEM V, binary and ternary mixes of OPC, metakaolin and slag) [3, 17-19].

- The Ca-oxalate and Ca-succinate salts present several degrees of hydration (or numbers of water molecules in their stoichiometry). Calcium succinate mono- and tri-hydrate are reported in the literature $[40,41]$. However, very few solubility data can be found for these salts. Ca-succinate tri-hydrates, formally identified in experiments of immersion of cement paste in succinic acid $[42,43]$ was thus only considered in the calculation on the basis of handbook of chemistry data [37].

- Complementary data for $\mathrm{Fe}, \mathrm{K}, \mathrm{Mg}$ and $\mathrm{Na}$ complexation by the studied carboxylic acids are also available in the literature but they were not included for the sake of simplicity. That is to say, priority was given to two cementitious cations: $\mathrm{Ca}$, the major cationic element of most cement phases, and Al, which plays a key role in the behaviour of cement paste in acid environments.

- Data for hydroxyls and sulphates was taken from the same update of the MINTEQ base for reasons of consistency, (Table 4). These inorganic complexes are in competition with the conjugated bases of the acids in the alkaline range of $\mathrm{pH}$. 


\subsection{Chemical conditions}

\section{Carboxylic acid concentrations}

The total concentrations of carboxylic acids found in agrofood effluents are commonly high and range between several tens of mmol per litre for wine vinasses and several hundred mmol per litre for agricultural effluents (sugarcane vinasses, silage juices and liquid manure) [3, 18]. Accordingly, several tests of cement paste leaching by carboxylic acid solutions have been performed with acid concentrations of $280 \mathrm{mmol} / \mathrm{L}$ [18, 21, 44] or $300 \mathrm{mmol} / \mathrm{L}$ [19] with respect to the maximum concentration of acids found in liquid manure [3]. Also, total carboxylic acid concentrations have been measured in the range $300-400 \mathrm{mmol} / \mathrm{L}$ during experiments on the biodegradation of Portland cement paste by fungi [22].

To be more generic, the total concentration of carboxylic acid considered in the present speciation modelling was rounded off to $100 \mathrm{mmol} / \mathrm{L}$. This value is still high and representative the range of our previous studies $[13,17,18,22]$, to examine the different chemical species present in solution and their respective concentrations. However, preliminary stability diagrams covered a wider range (from $10^{-5}$ to $1 \mathrm{~mol} / \mathrm{L}$ ) to highlight the major species in solution according to $\mathrm{pH}$ and acid concentration.

\section{Element concentrations}

The total concentrations of aluminium and calcium considered in the speciation modelling were chosen according to the results of leaching tests of Portland cement pastes [13, 21, 22]. Al total concentrations varied from 0.02 to $3 \mathrm{mmol} / \mathrm{L}$ and $\mathrm{Ca}$ total concentrations ranged from 0.1 to 100 $\mathrm{mmol} / \mathrm{L}$. Intermediate values, obtained with tests where cement paste was immersed in 0.28 $\mathrm{mmol} / \mathrm{L}$ acetic acid solution were selected as the reference, i.e. 0.5 and $20 \mathrm{mmol} / \mathrm{L}$ for $\mathrm{Al}$ and $\mathrm{Ca}$, respectively. These total concentrations are not far from the concentrations typically found in CEM I pore water. This upper range of total concentration is also supported by the increase in the apparent solubility of $\mathrm{Al}$ and $\mathrm{Ca}$ due to complexation by organic acids.

The total concentrations of silica $\left(\mathrm{H}_{4} \mathrm{SiO}_{4}\right)$ and sulphates $\left(\mathrm{SO}_{4}\right)$ are not directly related to complexation by organic acids like cations are. These concentrations were set to $100 \mathrm{mmoL} / \mathrm{L}$, that is to say equals to the total concentration of carboxylic acids, which helps to assess the relative affinity of inorganic versus organic complexation of $\mathrm{Al}$ and $\mathrm{Ca}$.

$$
p H
$$

The $\mathrm{pH}$ range of $10-13$ corresponds to the chemistry of cementitious materials (sound to slightly leached cement paste). The $\mathrm{pH}$ values measured in agrofood effluents or in solutions of bioleaching experiments are usually in the range $4-7$ [3, 13, 18, 21, 22]. A wide $\mathrm{pH}$ domain (pH $1-13$ ) was therefore considered in the speciation modelling for the sake of completeness.

\section{Modelling of acid properties and Ca stability diagrams}

\subsection{Acid titration and speciation}

This preliminary section introduces the relative complexity of organic acid with respect to $\mathrm{acid} /$ base reactions compared to nitric acid $\left(\mathrm{HNO}_{3}\right)$, which is commonly used in classical leaching tests devoted to acid attack of cement.

The modelling of acid titration by sodium hydroxide $(\mathrm{NaOH})$ is shown in. 1. Nitric acid is also given for comparison. The strength of the acid (i.e. weak or strong acid) is directly related to its $\mathrm{pKa}$ values. It reveals the level of dissociation for a given $\mathrm{pH}$. This is readily seen on the $\mathrm{pH}$ scale of the graph: nitric $>$ oxalic $>>$ citric $>$ succinic - acetic. Nitric acid is a strong acid (and the first $\mathrm{pKa}$ constant of oxalic acid is not far from the strong acid constant range). All the other acids are weak acids. Weak acids are characterized by their buffer zone. Fig. 1 shows that, for $\mathrm{pH}$ within 
[pKa-1, pKa+1], the addition of large quantities of base increases the $\mathrm{pH}$ of the solution only slightly. When cementitious specimens are exposed to weak acids, large amounts of hydroxyl ions can thus be released by the specimen with only a slight increase in the $\mathrm{pH}$ of the solution. This is useful in practical terms when leaching experiments are performed by monitoring the $\mathrm{pH}$ over time: the frequency of leaching solution changes is reduced (compared to strong acid solutions). For a given addition of $\mathrm{NaOH}$, the $\mathrm{pH}$ of the solution varies in accordance with the strengths of the acids (e.g., after the addition of $0.2 \mathrm{~mol} \mathrm{NaOH}, \mathrm{pH}=4.99$ for acetic, $\mathrm{pH}=4.26$ for succinic, $\mathrm{pH}=3.27$ for citric, $\mathrm{pH}=1.71$ for oxalic, and $\mathrm{pH}=1.22$ for nitric, as shown in Fig. 1). $\mathrm{A} \mathrm{pH}$ of 4 is the reference $\mathrm{pH}$ for several leaching tests in the literature $[44,45]$, since the $\mathrm{pH}$ interval $[4.0 ; 4.5]$ matches XA3 exposure class in standard NF EN 206-1 (i.e. an environment with high chemical aggressiveness). It should be noted that the addition of strong base to the aggressive solution in order to bring the $\mathrm{pH}$ up to a target value makes it necessary to take the possible precipitation of salt formed from the cation of the base and the conjugated base of the organic acid into account. This is the case for oxalic acid solutions in which sodium oxalate precipitates when sodium hydroxide is added because sodium oxalate is insoluble [44]. Consequently, most experiments with oxalic acid are carried out without any addition of base, and the initial $\mathrm{pH}$ of the solution is $1 / 2(\mathrm{pKa}-\log (\mathrm{c}))$, i.e. 1.2 for an acid concentration of $0.28 \mathrm{~mol} / \mathrm{L}$ (horizontal dotted line on Fig. 1).

Fig. 1 also clearly illustrates the poly-acidity property of the organic acids, as di-acids (succinic and oxalic) and tri-acids (citric) generate two and three times as many moles of acid as the monoacid (acetic, nitric) for the same initial concentration of acid $(0.28 \mathrm{~mol} / \mathrm{L}$, here $)$. In many cases, there is a convolution of the first and second acid functions, $\mathrm{pKa}_{1}$ and $\mathrm{pKa}_{2}$ being close to each other, which strongly smoothes the $\mathrm{pH}$ increase after the addition of $0.28 \mathrm{~mol}$ of $\mathrm{NaOH}$. With regard to the poly-acidity property only, all things being equal, the power of acid attack on cement phases increases with the poly-acidity feature: citric $>$ oxalic - succinic $>$ acetic - nitric. Nevertheless it should not be forgotten that the properties of the calcium salts, when the solubility and the chemical conditions are such that the salts precipitate during the attack, have a preponderant effect on the aggressiveness of the organic acids $[3,15,18]$. An experimental study showed, for example, that oxalic acid, a bi-acid, was little or not aggressive to the cement matrix because of the precipitation, in the outer layer, of insoluble Ca-oxalate salt, the appropriate molar volume of which sealed the porosity and protected the matrix against further attack [18] (see Table 1).The poly-acidity also has some practical implications for the leaching test protocol, where the acid solution is usually pre-neutralized to a value of 4 . At this $\mathrm{pH}$, the aggressiveness of nitric acid is considerably reduced $\left(10^{-4} \mathrm{~mol} / \mathrm{L}\right.$ of proton remaining to be released), while acetic, succinic and citric acids still have the capability to react with $\mathrm{NaOH}$ or portlandite (which are both strong bases): $0.24,0.43$ and $0.49 \mathrm{~mol} / \mathrm{L}$ of proton are still to be released by the three acids respectively.

Fig. 2 gives the speciation of the carboxylic acids and their conjugated bases with respect to $\mathrm{pH}$. The $\mathrm{pH}$ at which the acid evolves to its conjugated base has a significant implication for the occurrence of organometallic complexes on the one hand, and salts on the other hand, since complexation and precipitation of salts of cations $\mathrm{Al}$ and $\mathrm{Ca}$ are linked to the concentration of the anionic conjugated bases in solution. Nitric acid is a strong acid and the nitrate species $\mathrm{NO}_{3}{ }^{-}$(the conjugated base) is directly present in the full $\mathrm{pH}$ domain between 0 and 14 . This is also the case for the first conjugated base $\mathrm{H}$-oxalate. In contrast, acetate becomes the main species only for $\mathrm{pH}$ above 6 . The pKa distributions of citric and succinic acids are relatively narrow, which implies that different conjugated bases (e.g. citrate, citrate $^{2-}$ and citrate ${ }^{3-}$ ) can co-exist and compete for $\mathrm{Al}^{3+}$ complexation in the $\mathrm{pH}$ range $3-6$. Regarding precipitation of organometallic salts, it was shown that $\mathrm{Ca}$-citrate, $\mathrm{Ca}$-oxalate and $\mathrm{Ca}$-succinate precipitated from the most dissociated form of the corresponding acid [3, 18]. Fig. 2 shows that these forms of conjugated bases are present in solution in small quantities at $\mathrm{pH} 4$ for acetic, citric and succinic acids. They become predominant for $\mathrm{pH}$ higher than the second or third $\mathrm{pKa}$, which conditions the precipitation inside or outside the matrix depending on the relative values of the $\mathrm{pH}$ of the aggressive solution and of the $\mathrm{pKa}$, and thus the damage to the matrix when the salts are expansive. This is the case of Ca- 
succinate: $\mathrm{H}_{2} \mathrm{O}$ and Ca-citrate: $4 \mathrm{H}_{2} \mathrm{O}$, which precipitate in the matrix, producing moderate and severe cracking respectively (Table 1) $[18,42]$.

\subsection{Calculated solubility of calcium salts}

Table 5 indicates good agreement between the calculated and experimental solubility values of the salts consisting of calcium and the conjugated bases of organic acids (e.g. Ca-Succinate: $\mathrm{H}_{2} \mathrm{O}$ ). This strengthens our confidence that the thermodynamic data for citric and oxalic acids selected from the literature (the constants of $\mathrm{Ca}$-acetate and $\mathrm{Ca}$-succinate salts were fitted on the experimental data) are representative. By decreasing order of solubility, we have: acetate $>>$ succinate $>$ citrate $>>$ oxalate. Calcium acetate is particularly soluble whereas calcium oxalate is especially insoluble. It is noteworthy that, for the salts listed, the less the degree of hydration, the more stable the salt.

\subsection{Simplified stability/phase diagrams of calcium}

The simplified stability or phase diagrams of Figs. 3 and 4 give a general overview of the stability of the $\mathrm{Ca}$ salts with respect to $\mathrm{pH}$, and also of the activity of the conjugated bases, without considering sulphates (Fig. 3) or including sulphate species (Fig. 4). These diagrams are helpful to determine the aqueous species and solid phases that are stable when the $\mathrm{pH}$ or the acid concentration evolves, as well as to correlate with experimental results. The activity approximately corresponds to the concentration for activity $\leq 5 \times 10^{-2}$. Above, activity corrections would be required. It should be noted that the diagrams only represent the predominant species (with maximum activity). These graphs are representative of the competition between hydroxyl species, sulphates and the conjugated bases of acids, as well as of the differential solubility between the various solids.

Compared to the other organic acids, acetic acid has the weakest interactions with $\mathrm{Ca}$ and its salts have the highest solubility. Whatever the acetate activity, there is no salt precipitation because of the high solubility of $\mathrm{Ca}$-Acetate(s). The Ca-acetate(aq) complex only forms in solution for high activity of acetate $\left(>5 \times 10^{-2}\right.$ approximately), whereas cation $\mathrm{Ca}^{2+}$ is predominant at lower acetate activities. The $\mathrm{C}-\mathrm{S}-\mathrm{H}$ stability field is hardly impacted by the presence of acetic acid, except at very high acetate activity. The Ca-Acetate(s) salt is much less stable than gypsum while taking into account sulphates at a total concentration of 100 mmolal, and fully disappears from the phase diagram.

In contrast, citric and oxalic acids have the strongest effect on the chemistry of $\mathrm{Ca}$. In particular the Ca-oxalate salts are very little soluble, or even insoluble, and cover most of the diagram domain. Ca-(oxalate) $: 3 \mathrm{H}_{2} \mathrm{O}$ (caoxite) and Ca-(oxalate) $2 \mathrm{H}_{2} \mathrm{O}$ (weddellite) are slightly less insoluble than the mono hydrated form (whewellite), but all these salts can significantly destabilize $\mathrm{C}-\mathrm{S}-\mathrm{H}$ even at low activities. In experimental studies, the immersion of cement paste in $0.28 \mathrm{mmol} / \mathrm{L}$ oxalic acid solutions expressed itself by the precipitation of Ca:oxalate monohydrate. Gypsum has almost no competitive effect versus any of the Ca-Oxalate salts and is stable at very low oxalate activities only.

The unit-cell of the calcium citrate crystals is relatively complex, consisting of 2 citrate groups, 3 calcium atoms and 4 water molecules. This makes the salt expansive when it forms at the expense of cement phases [18]. $\mathrm{Ca}_{3}-(\text { Citrate })_{2}: 4 \mathrm{H}_{2} \mathrm{O}$ precipitates over a wide range of $\mathrm{pH}$ and citrate activity. It competes with the calcium of the $\mathrm{C}-\mathrm{S}-\mathrm{H}$ phase, decreasing its stability domain. This is consistent with experiments: abundant amounts of $\mathrm{Ca}_{3}-(\text { Citrate })_{2}: 4 \mathrm{H}_{2} \mathrm{O}$ were found in tests of cement matrix immersion in citric acid at $\mathrm{pH}$ 4. SEM observations coupled with EDS showed that the salt precipitated within the 'unaltered' zone - as defined by the phenolphthalein test - i.e. at $\mathrm{pH}>9.5$ [42]. However, the salt became soluble for $\mathrm{pH}<3-4.5$, depending on the citrate concentration, which explains the lack of citrate salt in leaching tests carried out at $\mathrm{pH} 4$ with an acetate-oxalate-citrate mixture [3]. Despite a rather high sulphate total concentration of 100 
mmolal, gypsum is only present at the bottom of the stability diagram for the lowest citrate activity.

Succinic acid shows intermediate properties between the weak influence of acetate and the significant effect of citric and oxalic acids both without and with sulphates. The stability field of $\mathrm{C}-\mathrm{S}-\mathrm{H}$ is almost unchanged and the solubility of Ca-succinate: $3 \mathrm{H}_{2} \mathrm{O}$ is moderate. This result is in accordance with the literature $[42,43]$. It was shown that the attack of cement paste by succinic acid resulted in the precipitation of small amounts of calcium succinate salts in the inner part of the degraded zone, close to the sound zone, i.e. at $\mathrm{pH}$ between 4 and 9.5 (the sound zone being defined by the change in colour of the phenolphthalein) (see Table 1).

\section{Aqueous speciation of $\mathrm{Al}$ and $\mathrm{Ca}$ versus $\mathrm{pH}$}

\subsection{Acetic acid}

Fig. 5 shows the concentrations of the different aqueous species of aluminium versus $\mathrm{pH}$ for the different carboxylic acids without considering any solids. The aqueous speciation of aluminium has a larger chemical variability with carboxylic acids than with inorganic acids such as $\mathrm{HNO}_{3}$. At acidic $\mathrm{pH}<4$, aluminium is mostly present as sulphate complexes $\left(\mathrm{AlSO}_{4}{ }^{+}\right.$and $\left.\mathrm{Al}\left(\mathrm{SO}_{4}\right)_{2}{ }^{-}\right)$. $\mathrm{Al}-$ acetate $^{2+}$ (binary complex, not shown) is also present at this $\mathrm{pH}$ range but at a low concentration. The species $\mathrm{HSO}_{4}{ }^{-}$is formed at very acidic $\mathrm{pH}$, which explains the relative decrease of $\mathrm{AlSO}_{4}{ }^{+}$ concentration at $\mathrm{pH} 1$.

In the moderately acidic to neutral $\mathrm{pH}$ range, the complexation of $\mathrm{AlOH}^{2+}$ by acetate (ternary complex) become the major species. It is noteworthy that the monohydroxyl complex $(\operatorname{logK}$ $\left.\mathrm{AlOH}^{2+}=9.00\right)$ has much higher affinity than the corresponding monoacetate complex (logK AlAcetate $\left.^{2+}=2.75\right)$. At $\mathrm{pH}$ values above neutrality $(\mathrm{pH}>7), \mathrm{Al}(\mathrm{OH})_{4}^{-}$is by far the predominant species.

Fig. 6 shows the concentrations of the different aqueous species of calcium versus $\mathrm{pH}$ for the different carboxylic acids without considering any solids. The aqueous speciation of calcium is dominated by the free cation $\mathrm{Ca}^{2+}$ and the binary sulphate complex $\mathrm{Ca}-\mathrm{Sulphate}\left(\mathrm{CaSO}_{4}\right)$ over the full $\mathrm{pH}$ range. The chemistry of calcium is also affected by acetate at $\mathrm{pH}$ above 4 but to a lesser extent. Calcium speciation is never controlled by the hydroxyl species, as found with aluminium, except at very alkaline $\mathrm{pH}(\mathrm{pH} 13)$.

\subsection{Citric acid}

The distribution of both $\mathrm{Al}$ and $\mathrm{Ca}$ species in a citric acid solution is more complicated than in an acetic acid solution (Figs. 5 and 6). This is directly related to the chemistry of citric acid and its conjugated bases (as shown in Fig. 2). The strength of the citrate-Al interaction is also stronger since $\mathrm{Al}(\mathrm{OH})_{4}{ }^{-}$becomes predominant only at $\mathrm{pH}$ higher than 10.5 . Nevertheless, this hydroxyl complex is still the major species found in the $\mathrm{pH}$ range of cement pore water. The quaternary complex $\mathrm{AlOH}-(\mathrm{Citrate})_{2}{ }^{4-}$ is the major species in the $\mathrm{pH}$ range $4-10$, whereas the ternary complex AlOH-Citrate dominates between $\mathrm{pH} 2$ and 4 . The sulphate species only occurs at very acidic $\mathrm{pH}$ where citrate is under its acid form $\mathrm{H}_{3}$-Citrate (Fig. 2). Therefore, the affinity of sulphates for aluminium is significantly weaker than citrate in contrast with acetate.

Below $\mathrm{pH} 4$, the aqueous speciation of calcium is again dominated by the free cation $\mathrm{Ca}^{2+}$ and the binary sulphate complex Ca-Sulphate $\left(\mathrm{CaSO}_{4}\right)$. With respect to citrate species, $\mathrm{Ca}^{2+}$ is complexed by the sequence $\mathrm{Ca}-\mathrm{H}_{2}$ citrate $^{+}$, Ca-Hcitrate(aq) and $\mathrm{Ca}$-citrate ${ }^{-}$as $\mathrm{pH}$ increases, as a result of the polyacidity of citric acid. Unlike acetic acid, calcium is completely complexed by citrate for $\mathrm{pH} \geq$ 4. The strong chelating effect of citric acid may contribute to the very high aggressiveness of the acid (Table 1) [18] since the formation of complexes can act as a pump for the calcium of the cement phases. 


\subsection{Oxalic acid}

Figs. 5 and 6 indicate that the aqueous speciation of $\mathrm{Al}$ and $\mathrm{Ca}$ in oxalic acid solution is similar in strength to that of citric acid. Al complexation by oxalates is stronger than citrates in the acidic range of $\mathrm{pH}$ where no significant sulphate complexation takes place. It is slightly less intense under moderately alkaline conditions where the $\mathrm{Al}(\mathrm{OH})_{4}{ }^{-}$species is dominant since $\mathrm{pH} \geq 9.5$. It is worth mentioning that in geochemistry montmorillonite dissolution is known to be more enhanced by citric acid than oxalic acid $[46,47]$.

Under $\mathrm{pH}<4$, the aqueous chemistry of calcium consists of $\mathrm{Ca}^{2+}$ and $\mathrm{CaSO}_{4}$ species. At higher $\mathrm{pH}$, oxalates readily form strong aqueous complexes with $\mathrm{Ca}^{2+}$ cations.

\subsection{Succinic acid}

As shown in Fig. 5, the Al-succinate speciation is especially complicated due to the combination of reactions of the two conjugated bases $\mathrm{H}$-succinate ${ }^{-}$and succinate ${ }^{2-}$ with the cations $\mathrm{Al}^{3+}$, $\mathrm{AlOH}^{2+}$ and $\mathrm{Al}(\mathrm{OH})_{2}{ }^{+}$. However, the sulphate-complexes are predominant at $\mathrm{pH}<4$ and the hydroxy-complex $\mathrm{Al}(\mathrm{OH})_{4}{ }^{-}$dominates above $\mathrm{pH}$ 8.5. Similarly to acetic acid, calcium does not form strong complexes with succinate ligands (Fig. 6).

\section{Solid speciation of $\mathrm{Al}$ and $\mathrm{Ca}$ versus $\mathrm{pH}$}

The correct modelling of the experimental leaching tests by organic acids requires a reactive transport approach that was out of the scope of the paper. A simplified CEM-I hydrate set was considered in addition to the stability/phase diagrams of calcium. This gave some insights into the relative affinity of carboxylic acid, hydroxyl, silica and sulphate for calcium and aluminium solid phases at different $\mathrm{pH}$. The initial cement-type hydrate consisted of $\mathrm{C}-\mathrm{S}-\mathrm{H} 1.6(100 \mathrm{mmol} / \mathrm{L}$, $0.02 \mathrm{~kg} / \mathrm{L})$, portlandite $(100 \mathrm{mmol} / \mathrm{L}, 0.008 \mathrm{~kg} / \mathrm{L})$ and ettringite $(20 \mathrm{mmol} / \mathrm{L}, 0.005 \mathrm{~kg} / \mathrm{L})$. The corresponding liquid/solid ratio $(\mathrm{L} / \mathrm{S}=30 \mathrm{~L} / \mathrm{kg})$ was about 500 times higher than in a hydrated CEM I paste $(\mathrm{L} / \mathrm{S} \approx 0.06 \mathrm{~L} / \mathrm{kg}$ assuming a porosity of $10 \%)$. The strong dilution avoided huge aqueous concentrations at acidic $\mathrm{pH}$ where all the cement phases are fully dissolved from the one hand, and led to total concentrations of silica and sulphate close to the total concentrations of carboxylic acids $(100 \mathrm{mmol} / \mathrm{L})$ from the other hand.

As a typical example, Fig. 7-A shows the evolution of calcium solid phases with respect to $\mathrm{pH}$ for a $100 \mathrm{mmol} / \mathrm{L}$ solution of succinic acid. Starting from the usual $\mathrm{pH}$ of cement hydrates $(\mathrm{pH}$ 13) towards more acidic $\mathrm{pH}$, one has portlandite dissolution, progressive $\mathrm{C}-\mathrm{S}-\mathrm{H}$ decalcification $(\mathrm{C} / \mathrm{S}$ 1.6, 1.2 and eventually 0.8 in the present case), to end in pure silica oxides (not shown) at $\mathrm{pH}$ below 9. Gypsum precipitates as the results of ettringite destabilisation below $\mathrm{pH} 10$ and remains stable up to $\mathrm{pH} 1$. All this corresponds to the usual cement degradation pattern, which indirectly gives some representativeness of the simplified approach to model cement mineralogy. The Casuccinate salt can co-exist with the cement and secondary solid phases between $\mathrm{pH} 12.5$ and 4 .

Fig. 7-B indicates the relative range of Ca-salt stability under similar calculations and conditions for the other carboxylic acids. Ca-acetate never precipitates, whereas Ca-oxalate is highly stable over the full $\mathrm{pH}$ range. Ca-oxalate salts were indeed found to precipitate in the outer layer of cement paste specimens, in the so-called unaltered zone, i.e. at $\mathrm{pH}>9.5$ (as defined by the change in colour of phenolphthalein) (Table 1, [42, 48]). $\mathrm{Ca}_{3}-(\text { Citrate })_{2}: 4 \mathrm{H}_{2} \mathrm{O}$ is also characterized by a wide $\mathrm{pH}$-range of stability. The partial dissolution at $\mathrm{pH} 5$ is an artefact of the present modelling approach due to $\mathrm{Al}$ aqueous complexation once gibbsite is totally dissolved, as shown in Fig. 7-C. This Figure illustrates the stronger effect of citrate complexation versus acetate complexation of aluminium with respect to gibbsite stability. The reduction of the stability domain of gibbsite can be related to experiments on the leaching of montmorillonite by citric acid, where Al complexation by citrates played an important role [46]. On the contrary, ettringite stability remains unaffected by citrate complexation since the hydroxyl complex $\mathrm{Al}(\mathrm{OH})_{4}{ }^{-}$predominates at 
$\mathrm{pH}$ above 9. However, great care should be taken here since experiments have shown that Aloxalate salts are insoluble, although no quantitative solubility data (in chemical conditions close to those considered here) were found.

\section{Speciation of acid mixture}

In the modelling shown in Fig. 8, the total acid concentration was set to $400 \mathrm{mmol} / \mathrm{L}$ and uniformly distributed among the carboxylic acids (i.e. four times $100 \mathrm{mmol} / \mathrm{L}$ ). The relative affinities of the complexes and the relative stabilities of the calcium salts are in full agreement with the previous results. The main $\mathrm{Al}$ complexes are the oxalate species in the $\mathrm{pH}$ range $2-6$, replaced by the citrate complexes up to $\mathrm{pH} 10$, above which the hydroxyl species predominated (Fig. 8-A). A similar trend is obtained for calcium: first oxalate species, then citrate species and, eventually, though at much higher $\mathrm{pH}$, the hydroxyl complex, successively formed in solution (Fig. 8-B). In any case, acetate or succinate species are at very low concentrations. When the cement-type hydrates and the secondary solid phases are considered, Ca-oxalate: $\mathrm{H}_{2} \mathrm{O}$ is the most stable salt that precipitates in agreement with its largest stability domain in the stability/phase diagrams of Figs. 3 - 4. All the available oxalates are consumed by this precipitation since the $\mathrm{Ca}-\mathrm{Oxalate}$ salt reaches a concentration of $100 \mathrm{mmol} / \mathrm{L}$ (Fig. 8-C). Citrate, succinate and sulphate salts can only co-exist with $\mathrm{Ca}$-Oxalate provided the calcium total concentration is in excess with respect to oxalate total concentration (additional calculations not shown in Fig. 8-C). This is in accordance with experiments by Larreur-Cayol et al. [13] and Voegel et al. [14] on mixes of acids (acetic-oxalic and acetic-oxalic-citric), summarized in Table 1, that showed that the presence of oxalic acid in the aggressive solution protected the matrix by the precipitation of Ca-oxalate at the surface of the Portland cement specimens, even in the presence of the very aggressive citric acid and for $\mathrm{pH}$ as low as 1 . It should be noted that, in these immersion experiments, different forms of calcium oxalate salts were identified in the outer part of the matrix: mono-, di- and/or tri-acids were found, depending on the concentrations of the acids $[8,14,48]$. In particular, with aceticoxalic mixtures $(2 / 3-1 / 3$, total concentration of acids: $0.28 \mathrm{~mol} / \mathrm{L})$, Ca-oxalate di-hydrate was found in a mix of salts with Ca-oxalate mono-hydrate. This difference in the precipitation form of Ca-oxalate in the experimental studies between oxalic acid alone and the acetic-oxalic mixture could be linked to the oxalate- or calcium-dependent nature of the two salts [49]. The present thermodynamic equilibrium approach did not simulate the occurrence of several types of Caoxalate salts, which probably means that kinetic modelling is required.

It is clear that citrates and oxalates dominate over acetates and succinates in the chemistry. The properties modelled for each acid separately are maintained in a mixture of organic acids. Consequently, it seems that organic/cement systems of increasing complexity can be explored step by step.

\section{Conclusion}

The durability of cementitious materials may be strongly questioned once they come into contact with short-chain organic acids dissolved in effluents under the specific conditions encountered in agriculture, the agrofood industry and radioactive waste disposals. The reactivity is driven by three main processes: the (poly)-acidity of the acid on the one hand, and the complexation and salt precipitation induced by their conjugated bases on the other hand. Full modelling of such interactions requires the coupling of chemistry, diffusion properties and, possibly, mechanics. However, chemistry is a central issue that, in a first stage, required thermodynamic data (pKa, complexation constant, solubility products) to be gathered from different literature sources and some insights into their basic speciation to be gained with the main cementitious cations $\left(\mathrm{Al}^{3+}\right.$ and $\mathrm{Ca}^{2+}$ ). The data collected seem consistent and sufficient to simulate the speciation of the four acids studied over the full $\mathrm{pH}$ domain, although succinic acid gives the most reduced set of species. More generally, the lack of experimental studies on ternary complexes and, above all, on Al-salt solubility is still a limitation when modelling the full complexity of organic acid 
chemistry. The thermodynamics of the sorption of the conjugated bases on cement phases was not considered in the present modelling either.

The large variability of chemical species makes the acid attack of cement matrix by organic acids different from classical attacks by strong inorganic acids. Many specific features, already identified in the experimental literature, have been quantitatively reproduced here, such as the importance of polyacidity, the additional capacity for proton-release of weak acids compared to strong acids once neutralized at $\mathrm{pH} 4$, the competition of $\mathrm{Al}$ complexation between the conjugated bases, sulphates and the hydroxyls (the species $\mathrm{Al}(\mathrm{OH})_{4}{ }^{-}$being systematically predominant at alkaline $\mathrm{pH}$ ), and the varied solubility of the salts formed from $\mathrm{Ca}$ and the conjugated bases. Globally, from the point of view of $\mathrm{Al}$ and Ca chemistry, acetic acid has a relatively weak effect whereas citric and oxalic acid have a strong impact (succinic acids show intermediate behaviour). Citric and oxalic acids were found to have a strong chelating effect compared to acetic acid, while succinic showed intermediate behaviour. The reverse tendency was found for Ca-salt solubility, acetate being very soluble and oxalate very insoluble. Interestingly, the properties modelled for each acid separately were kept in a mixture of organic acids (e.g. oxalates and citrates dominated the chemistry over acetates and succinates).

However, these findings have to be balanced by the coupling with transport parameters to fully assess of the durability of a hydrated cement paste. The properties of the salts are of prime importance in the alteration process. The low solubility of Ca-oxalate salts tends to prevent alteration by means of a protective layer and an appropriate molar volume, whereas the expansive nature of citrate Ca-salts favours the mechanical failure of cement microstructure. Moreover some properties of the salts, such as their affinity for the matrix and their mesoscopic forms were assumed to influence their aggressiveness. These effects need to be better characterized [3, 48]. Work is in progress to include the acquired thermodynamics in reactive transport modelling of cement phase interactions with organic acids.

\section{Acknowledgments.}

The constructive and detailed comments of two anonymous reviewers are gratefully acknowledged.

\section{References}

[1] N. De Belie, "A Survey on concrete floors in pig houses and their degradation," J. Agric. Eng. Res., vol. 66, no. 3, pp. 151-156, Mar. 1997.

[2] A. Bertron, M. Coutand, X. Cameleyre, G. Escadeillas, and J. Duchesne, "Attaques chimique et biologique des effluents agricoles et agroalimentaires sur les matériaux cimentaires," Matér. Tech., vol. 93, p. s.111-s.121, Apr. 2006.

[3] A. Bertron and J. Duchesne, "Attack of Cementitious Materials by Organic Acids in Agricultural and Agrofood Effluents," in Performance of Cement-Based Materials in Aggressive Aqueous Environments, M. Alexander, A. Bertron, and N. D. Belie, Eds. Springer Netherlands, 2013, pp. 131-173.

[4] I. Walczak, M. Libert, S. Camaro, and J. M. Blanchard, "Quantitative and qualitative analysis of hydrosoluble organic matter in bitumen leachates," Agronomie, vol. 21, no. 3, pp. 247-257, Apr. 2001.

[5] M. Libert and I. Walczak, "Effect of radio-oxidative ageing and $\mathrm{pH}$ on the release of soluble organic matter from bitumen," Avignon, 2000, p. 4.

[6] L. R. Van Loon and Z. Kopajtic, "Complexation of $\mathrm{Cu}^{2+}, \mathrm{Ni}^{2+}$ and $\mathrm{UO}_{2}{ }^{2+}$ by radiolytic degradation products of bitumen," Nagra, Technical Report NTB 90-18, 1990.

[7] A. Kagawa, M. Fukumoto, and K. Kawamura, "Influence of Chemical and Radiolytic Degradation of Bitumen on Its Performance for Disposal," J. Nucl. Sci. Technol., vol. 37, no. 10, pp. 934-937, 2000. 
[8] A. Bertron, N. Jacquemet, B. Erable, C. Sablayrolles, G. Escadeillas, and A. Albrecht, "Reactivity of nitrate and organic acids at the concrete-bitumen interface of a nuclear waste repository cell," Nucl. Eng. Des., vol. 268, pp. 51-57, Mar. 2014.

[9] M. Alquier, C. Kassim, A. Bertron, C. Sablayrolles, A. Albrecht, and B. Erable, "Halomonas desiderata as a bacterial model to predict the possible biological nitrate reduction in concrete cells of nuclear waste disposals," J. Environ. Manage., vol. 132, pp. 32-41, 2014.

[10] A. Albrecht, A. Bertron, and M. Libert, "Microbial Catalysis of Redox Reactions in Concrete Cells of Nuclear Waste Repositories: A Review and Introduction," in Cement-Based Materials for Nuclear Waste Storage, F. Bart, C. Cau-di-Coumes, F. Frizon, and S. Lorente, Eds. New York, NY: Springer New York, 2013, pp. 147-159.

[11] M. A. Glaus, L. R. van Loon, S. Achatz, A. Chodura, and K. Fischer, "Degradation of cellulosic materials under the alkaline conditions of a cementitious repository for low and intermediate level radioactive waste: Part I: Identification of degradation products," Anal. Chim. Acta, vol. 398, no. 1, pp. 111-122, Oct. 1999.

[12] N. K. Singh, P. C. Mishra, V. K. Singh, and K. K. Narang, "Effects of hydroxyethyl cellulose and oxalic acid on the properties of cement," Cem. Concr. Res., vol. 33, no. 9, pp. 13191329, Sep. 2003.

[13] S. Larreur-Cayol, L. De Windt, A. Bertron, and G. Escadeillas, "Deterioration of cementitious materials by organic acids in agricultural effluents: experiments and modelling," presented at the 7th International Symposium on Cement Based Materials for a Sustainable Agriculture; CIGR International Symposium, 2011, pp. 38-46.

[14] C. Voegel, A. Bertron, B. Erable, and G. Escadeillas, "Chemical treatment with oxalic acid to improve the durability of cement-based materials in acid environments," in Proceedings of the International Conference on Durability of Building Materials and Components, Sao Paulo, 2014.

[15] A. Bertron, "Understanding the interactions between cementitious materials, microorganisms and organic matter: a key to durable and sustainable concrete structures in various contexts," Mater. Struct., 2014. DOI: 10.1617/s11527-014-0433-1.

[16] J. Duchesne and A. Bertron, "Leaching of Cementitious Materials by Pure Water and Strong Acids $\left(\mathrm{HCl}\right.$ and $\left.\mathrm{HNO}_{3}\right)$," in Performance of Cement-Based Materials in Aggressive Aqueous Environments, M. Alexander, A. Bertron, and N. D. Belie, Eds. Springer Netherlands, 2013, pp. 91-112.

[17] A. Bertron, J. Duchesne, and G. Escadeillas, "Accelerated tests of hardened cement pastes alteration by organic acids: analysis of the pH effect," Cem. Concr. Res., vol. 35, no. 1, pp. 155-166, 2005.

[18] S. Larreur-Cayol, A. Bertron, and G. Escadeillas, "Degradation of cement-based materials by various organic acids in agro-industrial waste-waters," Cem. Concr. Res., vol. 41, no. 8, pp. 882-892, 2011.

[19] O. Oueslati and J. Duchesne, "The effect of SCMs and curing time on resistance of mortars subjected to organic acids," Cem. Concr. Res., vol. 42, no. 1, pp. 205-214, Jan. 2012.

[20] A. Bertron, J. Duchesne, and G. Escadeillas, "Degradation of cement pastes by organic acids," Mater. Struct., vol. 40, no. 3, pp. 341-354, 2007.

[21] A. Bertron, J. Duchesne, and G. Escadeillas, "Attack of cement pastes exposed to organic acids in manure," Cem. Concr. Compos., vol. 27, no. 9-10, pp. 898-909, Nov. 2005.

[22] L. De Windt and P. Devillers, "Modeling the degradation of Portland cement pastes by biogenic organic acids," Cem. Concr. Res., vol. 40, no. 8, pp. 1165-1174, août 2010.

[23] D. Damidot, B. Lothenbach, D. Herfort, and F. P. Glasser, "Thermodynamics and cement science," Cem. Concr. Res., vol. 41, pp. 679-695, 2011.

[24] J. van der Lee, L. De Windt, and P. Lagneau, "Module-oriented modeling of reactive transport with HYTEC," Comput. Geosci., vol. 29, pp. 265-275, 2003.

[25] J. P. Gustafsson, "Visual Minteq release 2.20 (Geochemist Workbench version made available by C. Bethke). http://www2.lwr.kth.se/English/OurSoftware/vminteq/verhistory.htm." 2003. 
[26] T. Wolery, "EQ3/6. A software package for geochemical modelling of aqueous systems: package overview and installation guide (version 7.0)," ed., Lawrence Livermore National Laboratory (USA), Technical Report UCRL-MA-110662 PT I, 1992.

[27] L. Duro, M. Grivé, and E. Giffaut, "ThermoChimie, the ANDRA Thermodynamic Database," MRS Online Proc. Libr., vol. 1475, p. null-null, 2012.

[28] W. Hummel, G. Anderegg, L. Rao, I. Puigdomènech, and Osamu Tochiyama, Chemical Thermodynamics Series Volume 9: Chemical thermodynamics of compounds and complexes of $U$, $\mathrm{Np}, \mathrm{Pu}, \mathrm{Am}, \mathrm{Tc}, \mathrm{Se}, \mathrm{Ni}$ and $\mathrm{Zr}$ with selected organic ligands. Amsterdam (The Netherlands): Elsevier, 2005.

[29] N. A. Lange and J. A. Dean, Lange's Handbook of chemistry. New York, N.Y.: McGraw-Hill, 1985.

[30] J. Streit, L.-C. Tran-Ho, and E. Königsberger, "Solubility of the Three Calcium Oxalate Hydrates in Sodium Chloride Solutionsand Urine-Like Liquors," Monatshefte Für Chem. Chem. Mon., vol. 129, no. 12, pp. 1225-1236, 1998.

[31] A. Seidell, Solubilities of Inorganic and Organic Compounds: A Compilation of Quantitative Solubility Data from the Periodical Literature. D. Van Nostrand Company, 1919.

[32] N. B. Walsdorf, G. Alexandrides, and C. Y. C. Pak, "Ultradense and more soluble and bioavailable preparations of calcium citrate," 4814177, 1989.

[33] D. J. Kok and S. R. Khan, "Calcium oxalate nephrolithiasis, a free or fixed particle disease," Kidney Int., vol. 46, no. 3, pp. 847-854, 1994.

[34] E. V. Petrova, N. V. Gvozdev, and L. N. Rashkovich, "Growth and dissolution of calcium oxalate monohydrate (COM) crystals," J. Optoelectron. Adv. Mater., vol. 6, no. 1, pp. 261-268, 2004.

[35] S. Sandersius and P. Rez, "Morphology of crystals in calcium oxalate monohydrate kidney stones," Urol. Res., vol. 35, no. 6, pp. 287-293, 2007.

[36] O. J. Walker, "IX.- Solubility of bi-bivalent salts in solutions containing a common ion," J. Chem. Soc. Trans., vol. 127, pp. 61-66, 1925.

[37] R. C. Weast, CRC Handbook of Chemistry and Physics, 58th Edition. Boca Raton, Florida: CRC Press, 1977.

[38] P. Blanc, A. Lassin, P. Piantone, M. Azaroual, N. Jacquemet, A. Fabbri, and E. C. Gaucher, "Thermoddem: A geochemical database focused on low temperature water/rock interactions and waste materials," Appl. Geochem., vol. 27, no. 10, pp. 2107-2116, Oct. 2012.

[39] L. De Windt, D. Deneele, and N. Maubec, "Kinetics of lime/bentonite pozzolanic reactions at 20 and $50{ }^{\circ} \mathrm{C}$ : Batch tests and modeling," Cem. Concr. Res., vol. 59, pp. 34-42, 2014.

[40] A. Karipides and A. T. Reed, "The structure of diaquasuccinatocalcium(II) monohydrate," Acta Crystallogr. B, vol. 36, no. 6, pp. 1377-1381, Jun. 1980.

[41] M. Mathew, S. Takagi, B. O. Fowler, and M. Markovic, "The crystal structure of calcium succinate monohydrate," J. Chem. Crystallogr., vol. 24, no. 7, pp. 437-440, Aug. 2012.

[42] A. Bertron, S. Larreur-Cayol, and T. M. T. Le, "Degradation of cementitious materials by some organic acids found in agroindutrial effluents," presented at the Final Conference of RILEM TC 211-PAE, Toulouse, 2009, vol. 1, pp. 96-107.

[43] S. Larreur-Cayol, "Attaques des matériaux cimentaires par les acides organiques des effluents agricoles et agro-alimentaires," Thèse de Doctorat, Université Paul Sabatier, Toulouse III, 2012.

[44] A. Bertron, "Methods for Testing Cementitious Materials Exposed to Organic Acids," in Performance of Cement-Based Materials in Aggressive Aqueous Environments, M. Alexander, A. Bertron, and N. D. Belie, Eds. Springer Netherlands, 2013, pp. 355-387.

[45] M. Castellote, "Tests for Leaching and Degradation in Soft or Carbonated Waters," in Performance of Cement-Based Materials in Aggressive Aqueous Environments, M. Alexander, A. Bertron, and N. D. Belie, Eds. Springer Netherlands, 2013, pp. 235-250.

[46] M. E. Ramos, S. Garcia-Palma, M. Rozalen, C. T. Johnston, and F. J. Huertas, "Kinetics of montmorillonite dissolution: An experimental study of the effect of oxalate," Chem. Geol., vol. 363, pp. 283-292, Jan. 2014. 
[47] M. E. Ramos, C. Cappelli, M. Rozalén, S. Fiore, and F. J. Huertas, "Effect of lactate, glycine, and citrate on the kinetics of montmorillonite dissolution," Am. Mineral., vol. 96, no. 56, pp. 768-780, May 2011.

[48] S. Larreur-Cayol, A. Bertron, R. San Nicolas, and G. Escadeillas, "Durability of different binders in synthetic agricultural effluents," in Proceedings of the 7th International Symposium on Cement Based Materials for a Sustainable Agriculture; CIGR International Symposium, Quebec, 2011, pp. 56-66.

[49] M. Daudon, P. Jungers, and B. Lacour, "Clinical interest of crystalluria study," Ann. Biol. Clin. (Paris), vol. 62, no. 4, pp. 379-393, Aug. 2004. 
Table 1.

Summary of alteration phenomena observed on ordinary Portland cement paste specimens immersed in organic acids alone or in mixtures (synthesis of experimental campaigns exposed in $[3,14,15,18])$. The total concentration of acids $=0.28 \mathrm{~mol} / \mathrm{L}$ and $\mathrm{pH}=4(\mathrm{pH}=1.2$ for citric $)$.

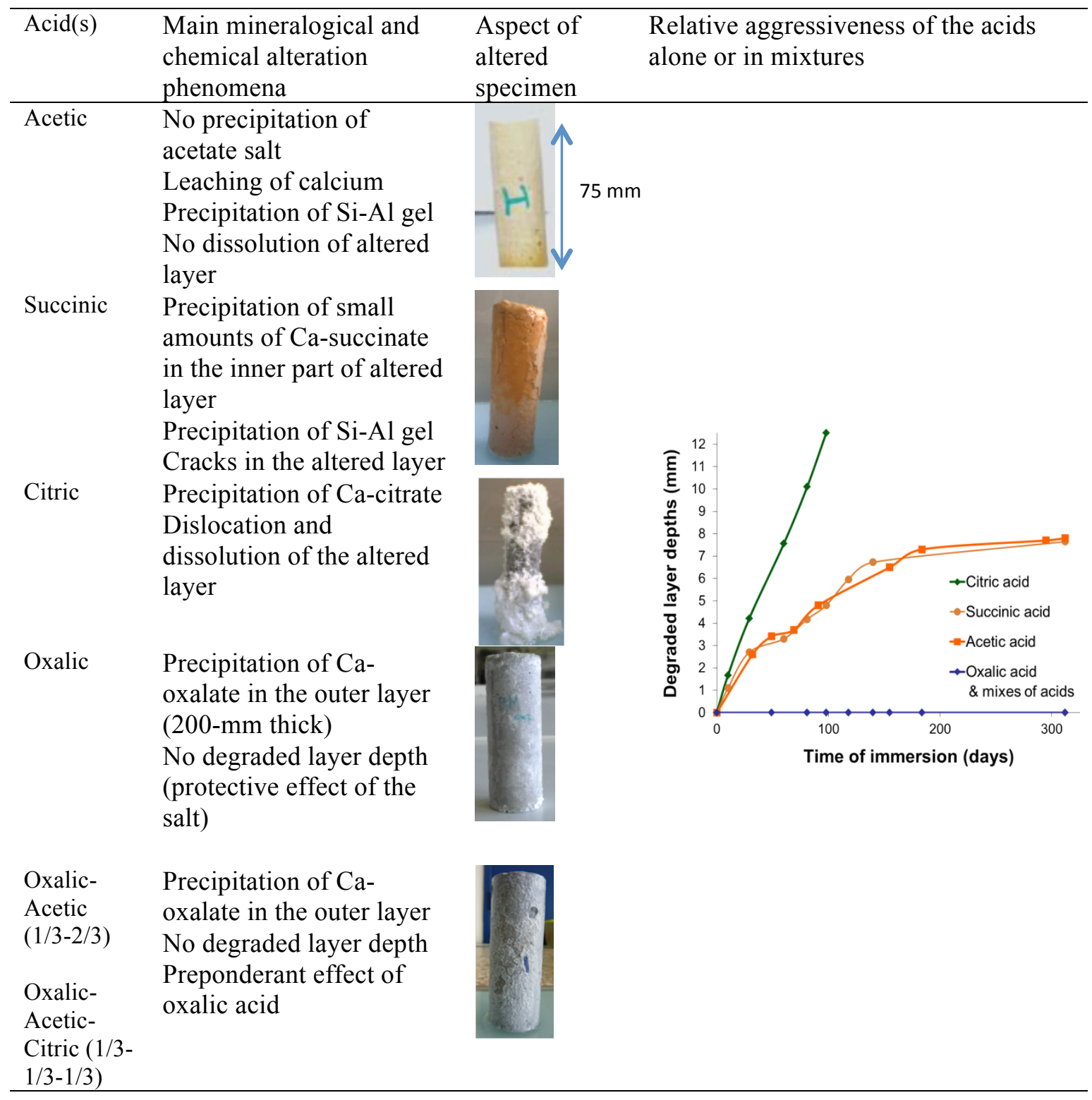




\section{Table 2.}

Carboxylic aqueous species: thermodynamic equilibrium constants (mass balance equation) at $25^{\circ} \mathrm{C}$.

\begin{tabular}{|c|c|c|c|}
\hline Species & Reaction of formation & $\log \mathrm{K}$ & Ref. ${ }^{(a)}$, note \\
\hline Acetic acid & $\mathrm{C}_{2} \mathrm{H}_{4} \mathrm{O}_{2}=\mathrm{CH}_{3}-\mathrm{COOH}$ & & \\
\hline H-Acetate & $\mathrm{H}^{+}+\mathrm{C}_{2} \mathrm{H}_{3} \mathrm{O}_{2}^{-} \rightarrow \mathrm{C}_{2} \mathrm{H}_{4} \mathrm{O}_{2}$ & 4.76 & {$[25], \sim[26]$} \\
\hline Al-Acetate ${ }^{2+}$ & $\mathrm{Al}^{3+}+\mathrm{C}_{2} \mathrm{H}_{3} \mathrm{O}_{2}^{-} \rightarrow \mathrm{AlC}_{2} \mathrm{H}_{3} \mathrm{O}_{2}^{2+}$ & 2.75 & {$[25]$} \\
\hline Al-(Acetate $)_{2}^{+}$ & $\mathrm{Al}^{3+}+2 \mathrm{C}_{2} \mathrm{H}_{3} \mathrm{O}_{2}^{-} \rightarrow \mathrm{Al}\left(\mathrm{C}_{2} \mathrm{H}_{3} \mathrm{O}_{2}\right)_{2}^{+}$ & 4.60 & {$[25]$} \\
\hline $\mathrm{AlOH}-\mathrm{Acetate}^{+}$ & $\mathrm{Al}^{3+}+\mathrm{C}_{2} \mathrm{H}_{3} \mathrm{O}_{2}^{-}+\mathrm{H}_{2} \mathrm{O} \rightarrow \mathrm{AlOHC}_{2} \mathrm{H}_{3} \mathrm{O}_{2}^{+}+\mathrm{H}^{+}$ & -0.15 & {$[25]$} \\
\hline $\mathrm{Al}_{2}(\mathrm{OH})_{2}$-Acetate ${ }^{3+}$ & $2 \mathrm{Al}^{3+}+\mathrm{C}_{2} \mathrm{H}_{3} \mathrm{O}_{2}^{-}+2 \mathrm{H}_{2} \mathrm{O} \rightarrow \mathrm{Al}_{2}(\mathrm{OH})_{2} \mathrm{C}_{2} \mathrm{H}_{3} \mathrm{O}_{2}^{3+}+2 \mathrm{H}^{+}$ & -2.41 & {$[25]$} \\
\hline $\mathrm{Ca}^{-A_{c} e t a t e^{+}}$ & $\mathrm{Ca}^{2}+\mathrm{C}_{2} \mathrm{H}_{3} \mathrm{O}_{2}^{-} \rightarrow \mathrm{CaC}_{2} \mathrm{H}_{3} \mathrm{O}_{2}^{+}$ & 1.18 & {$[25], \sim[26]$} \\
\hline $\mathrm{Ca}-(\text { Acetate })_{2}(\mathrm{aq})^{(\mathrm{b})}$ & $\mathrm{Ca}^{2+}+2 \mathrm{C}_{2} \mathrm{H}_{3} \mathrm{O}_{2}^{-} \rightarrow \mathrm{Ca}\left(\mathrm{C}_{2} \mathrm{H}_{3} \mathrm{O}_{2}\right)_{2}$ & 2.15 & {$[26]$} \\
\hline Citric acid & $\mathrm{C}_{6} \mathrm{H}_{8} \mathrm{O}_{7}=\mathrm{HOOC}-\mathrm{CH}_{2}-(\mathrm{COOH}) \mathrm{C}(\mathrm{OH})-\mathrm{CH}_{2}-\mathrm{COOH}$ & & \\
\hline $\mathrm{H}_{3}$-Citrate & $3 \mathrm{H}^{+}+\mathrm{C}_{6} \mathrm{H}_{5} \mathrm{O}_{7}^{3-} \rightarrow \mathrm{C}_{6} \mathrm{H}_{8} \mathrm{O}_{7}$ & 14.29 & {$[25], \sim[27]$} \\
\hline $\mathrm{H}_{2}$-Citrate ${ }^{-}$ & $2 \mathrm{H}^{+}+\mathrm{C}_{6} \mathrm{H}_{5} \mathrm{O}_{7}^{3-} \rightarrow \mathrm{C}_{6} \mathrm{H}_{7} \mathrm{O}_{7}^{-}$ & 11.16 & {$[25], \sim[27]$} \\
\hline H-Citrate ${ }^{2-}$ & $\mathrm{H}^{+}+\mathrm{C}_{6} \mathrm{H}_{5} \mathrm{O}_{7}^{3-} \rightarrow \mathrm{C}_{6} \mathrm{H}_{6} \mathrm{O}_{7}^{2-}$ & 6.40 & {$[25], \sim[27]$} \\
\hline Al-Citrate & $\mathrm{Al}^{3+}+\mathrm{C}_{6} \mathrm{H}_{5} \mathrm{O}_{7}^{3-} \rightarrow \mathrm{Al} \mathrm{C}_{6} \mathrm{H}_{5} \mathrm{O}_{7}$ & 9.98 & {$[25], \sim[27]$} \\
\hline Al-(Citrate $)_{2}^{3-}$ & $\mathrm{Al}^{3+}+2 \mathrm{C}_{6} \mathrm{H}_{5} \mathrm{O}_{7}^{3-} \rightarrow \mathrm{Al}\left(\mathrm{C}_{6} \mathrm{H}_{5} \mathrm{O}_{7}\right)_{2}^{3-}$ & 14.83 & {$[25], \sim[27]$} \\
\hline AlH-Citrate ${ }^{+}$ & $\mathrm{Al}^{3+}+\mathrm{H}^{+}+\mathrm{C}_{6} \mathrm{H}_{5} \mathrm{O}_{7}^{3-} \rightarrow \mathrm{Al} \mathrm{C}_{6} \mathrm{H}_{6} \mathrm{O}_{7}^{+}$ & 12.85 & {$[25], \sim[27]$} \\
\hline AlOH-Citrate ${ }^{-}$ & $\mathrm{Al}^{3+}+\mathrm{C}_{6} \mathrm{H}_{5} \mathrm{O}_{7}^{3-}+\mathrm{H}_{2} \mathrm{O} \rightarrow \mathrm{AlOHC}_{6} \mathrm{H}_{6} \mathrm{O}_{7}^{-}+\mathrm{H}^{+}$ & 8.10 & {$[25]$} \\
\hline $\mathrm{AlOH}-(\mathrm{Citrate})_{2}^{4-}$ & $\mathrm{Al}^{3+}+2 \mathrm{C}_{6} \mathrm{H}_{5} \mathrm{O}_{7}^{3-}+\mathrm{H}_{2} \mathrm{O} \rightarrow \operatorname{AlOH}\left(\mathrm{C}_{6} \mathrm{H}_{6} \mathrm{O}_{7}\right)_{2}^{4-}+\mathrm{H}^{+}$ & 10.19 & {$[25]$} \\
\hline Ca-Citrate ${ }^{-}$ & $\mathrm{Ca}^{2+}+\mathrm{C}_{6} \mathrm{H}_{5} \mathrm{O}_{7}^{3-} \rightarrow \mathrm{Ca} \mathrm{C}_{6} \mathrm{H}_{5} \mathrm{O}_{7}^{-}$ & 4.87 & {$[25], \sim[28]$} \\
\hline CaH-Citrate & $\mathrm{Ca}^{2+}+\mathrm{H}^{+}+\mathrm{C}_{6} \mathrm{H}_{5} \mathrm{O}_{7}^{3-} \rightarrow \mathrm{Ca} \mathrm{C}_{6} \mathrm{H}_{6} \mathrm{O}_{7}$ & 9.26 & {$[25], \sim[28]$} \\
\hline $\mathrm{CaH}_{2}-\mathrm{Citrate}^{+}$ & $\mathrm{Ca}^{2+}+2 \mathrm{H}^{+}+\mathrm{C}_{6} \mathrm{H}_{5} \mathrm{O}_{7}^{3-} \rightarrow \mathrm{Ca} \mathrm{C}_{6} \mathrm{H}_{7} \mathrm{O}_{7}^{+}$ & 12.59 & {$[25], \sim[28]$} \\
\hline Oxalic acid & $\mathrm{C}_{2} \mathrm{H}_{2} \mathrm{O}_{4}=\mathrm{HOOC}-\mathrm{COOH}$ & & \\
\hline $\mathrm{H}_{2}$-Oxalate & $2 \mathrm{H}^{+}+\mathrm{C}_{2} \mathrm{O}_{4}{ }^{2-} \rightarrow \mathrm{C}_{2} \mathrm{H}_{2} \mathrm{O}_{4}$ & 5.22 & {$[25], \sim[28]$} \\
\hline H-Oxalate ${ }^{-}$ & $\mathrm{H}^{+}+\mathrm{C}_{2} \mathrm{O}_{4}^{2-} \rightarrow \mathrm{C}_{2} \mathrm{HO}_{4}^{-}$ & 4.27 & {$[25], \sim[28]$} \\
\hline Al-Oxalate $^{+}$ & $\mathrm{Al}^{3+}+\mathrm{C}_{2} \mathrm{O}_{4}^{2-} \rightarrow \mathrm{AlC}_{2} \mathrm{O}_{4}^{+}$ & 7.73 & [25] (c) \\
\hline Al-(Oxalate $)_{2}^{-}$ & $\mathrm{Al}^{3+}+2 \mathrm{C}_{2} \mathrm{O}_{4}^{2-} \rightarrow \mathrm{Al}\left(\mathrm{C}_{2} \mathrm{O}_{4}\right)_{2}^{-}$ & 13.41 & [25] (d) \\
\hline $\mathrm{Al}-(\text { Oxalate })_{3}{ }^{3-}$ & $\mathrm{Al}^{3+}+3 \mathrm{C}_{2} \mathrm{O}_{4}{ }^{2-} \rightarrow \mathrm{Al}\left(\mathrm{C}_{2} \mathrm{O}_{4}\right)_{3}^{3-}$ & 17.09 & [25] (e) \\
\hline AlH-Oxalate ${ }^{2+}$ & $\mathrm{Al}^{3+}+\mathrm{C}_{2} \mathrm{O}_{4}^{2-} \rightarrow \mathrm{AlC}_{2} \mathrm{HO}_{4}^{2+}$ & 7.46 & {$[25]$} \\
\hline AlOH-Oxalate & $\mathrm{Al}^{3+}+\mathrm{C}_{2} \mathrm{O}_{4}^{2-}+\mathrm{H}_{2} \mathrm{O} \rightarrow \mathrm{AlOHC}_{2} \mathrm{O}_{4}+\mathrm{H}^{+}$ & 2.57 & {$[25]$} \\
\hline $\mathrm{AlOH}-(\mathrm{Oxalate})_{2}{ }^{2-}$ & $\mathrm{Al}^{3+}+2 \mathrm{C}_{2} \mathrm{O}_{4}{ }^{2-}+\mathrm{H}_{2} \mathrm{O} \rightarrow \mathrm{AlOH}\left(\mathrm{C}_{2} \mathrm{O}_{4}\right)_{2}^{2-}+\mathrm{H}^{+}$ & 6.84 & {$[25]$} \\
\hline
\end{tabular}




\begin{tabular}{|c|c|c|c|}
\hline $\mathrm{Al}(\mathrm{OH})_{2}-\mathrm{Oxalate}{ }^{-}$ & $\mathrm{Al}^{3+}+\mathrm{C}_{2} \mathrm{O}_{4}{ }^{2-}+2 \mathrm{H}_{2} \mathrm{O} \rightarrow \mathrm{Al}(\mathrm{OH})_{2} \mathrm{C}_{2} \mathrm{O}_{4}^{-}+2 \mathrm{H}^{+}$ & -3.12 & {$[25]$} \\
\hline Ca-Oxalate & $\mathrm{Ca}^{2+}+\mathrm{C}_{2} \mathrm{O}_{4}^{2-} \rightarrow \mathrm{CaC}_{2} \mathrm{O}_{4}$ & 3.19 & {$[25], \sim[28]$} \\
\hline $\mathrm{Ca}-(\mathrm{Oxalate})_{2}^{2-}$ & $\mathrm{Ca}^{2+}+2 \mathrm{C}_{2} \mathrm{O}_{4}^{2-} \rightarrow \mathrm{Ca}\left(\mathrm{C}_{2} \mathrm{O}_{4}\right)_{2}^{2-}$ & 4.02 & {$[28]$} \\
\hline Succinic acid & $\mathrm{C}_{4} \mathrm{H}_{6} \mathrm{O}_{4}=\mathrm{HOOC}-\mathrm{CH}_{2}-\mathrm{CH}_{2}-\mathrm{COOH}$ & & \\
\hline $\mathrm{H}_{2}$-Succinate & $2 \mathrm{H}^{+}+\mathrm{C}_{4} \mathrm{H}_{4} \mathrm{O}_{4}{ }^{2-} \rightarrow \mathrm{C}_{4} \mathrm{H}_{6} \mathrm{O}_{4}$ & 9.84 & {$[25]$} \\
\hline H-Succinate ${ }^{-}$ & $\mathrm{H}^{+}+\mathrm{C}_{4} \mathrm{H}_{4} \mathrm{O}_{4}^{2-} \rightarrow \mathrm{C}_{4} \mathrm{H}_{5} \mathrm{O}_{4}^{-}$ & 5.64 & {$[25]$} \\
\hline Al-Succinate $^{+}$ & $\mathrm{Al}^{3+}+\mathrm{C}_{4} \mathrm{H}_{4} \mathrm{O}_{4}^{2-} \rightarrow \mathrm{Al} \mathrm{C}_{4} \mathrm{H}_{4} \mathrm{O}_{4}^{+}$ & 4.92 & {$[25]$} \\
\hline AlH-Succinate ${ }^{2+}$ & $\mathrm{Al}^{3+}+\mathrm{H}^{+}+\mathrm{C}_{4} \mathrm{H}_{4} \mathrm{O}_{4}^{2-} \rightarrow \mathrm{Al} \mathrm{C}_{4} \mathrm{H}_{5} \mathrm{O}_{4}^{2+}$ & 8.08 & {$[25]$} \\
\hline AlOH-Succinate & $\mathrm{Al}^{3+}+\mathrm{C}_{4} \mathrm{H}_{4} \mathrm{O}_{4}^{2-}+\mathrm{H}_{2} \mathrm{O} \rightarrow \mathrm{Al} \mathrm{OHC} \mathrm{H}_{4} \mathrm{O}_{4}+\mathrm{H}^{+}$ & 0.77 & {$[25]$} \\
\hline $\mathrm{Al}(\mathrm{OH})_{2}$-Succinate $^{-}$ & $\mathrm{Al}^{3+}+\mathrm{C}_{4} \mathrm{H}_{4} \mathrm{O}_{4}{ }^{2-}+2 \mathrm{H}_{2} \mathrm{O} \rightarrow \mathrm{Al}(\mathrm{OH})_{2} \mathrm{C}_{4} \mathrm{H}_{4} \mathrm{O}_{4}+2 \mathrm{H}^{+}$ & -4.48 & {$[25]$} \\
\hline Ca-Succinate & $\mathrm{Ca}^{2+}+\mathrm{C}_{4} \mathrm{H}_{4} \mathrm{O}_{4}{ }^{2-} \rightarrow \mathrm{Ca} \mathrm{C}_{4} \mathrm{H}_{4} \mathrm{O}_{4}$ & 2.00 & {$[25]$} \\
\hline CaH-Succinate $^{+}$ & $\mathrm{Ca}^{2+}+\mathrm{C}_{4} \mathrm{H}_{4} \mathrm{O}_{4}{ }^{2-}+\mathrm{H}^{+} \rightarrow \mathrm{Ca} \mathrm{C}_{4} \mathrm{H}_{5} \mathrm{O}_{4}{ }^{+}$ & 6.72 & {$[25]$} \\
\hline
\end{tabular}

(a) The symbol " " means that the second reference gives a similar, but not necessarily equal, constant; (b) In the case of Ca-(Acetate) $)_{2}$ only, the symbol (aq) has been used to discriminate the aqueous complex from the salt; (c) $\log \mathrm{K}=9.4$ in [27]; (d) $\log \mathrm{K}=15.4$ in [27]; (e) $\log \mathrm{K}=$ 18.3 in [27]. 


\section{Table 3.}

Carboxylic calcium salts and hydrated cement phases: thermodynamic equilibrium constants (mass balance equation) at $25^{\circ} \mathrm{C}$.

\begin{tabular}{|c|c|c|c|}
\hline Mineral & Reaction of formation & $\log \mathrm{K}$ & Ref \\
\hline $\mathrm{Ca}-(\text { Acetate })_{2}(\mathrm{~s})^{(\mathrm{a})}$ & $\mathrm{Ca}^{2+}+2 \mathrm{C}_{2} \mathrm{H}_{3} \mathrm{O}_{2}^{-} \rightarrow \mathrm{Ca}\left(\mathrm{C}_{2} \mathrm{H}_{3} \mathrm{O}_{2}\right)_{2}$ & $1.9^{(\mathrm{b})}$ & {$[29]$} \\
\hline $\mathrm{Ca}_{3}-(\text { Citrate })_{2}: 4 \mathrm{H}_{2} \mathrm{O}$ & $3 \mathrm{Ca}^{2+}+2 \mathrm{C}_{6} \mathrm{H}_{5} \mathrm{O}_{7}{ }^{3-}+4 \mathrm{H}_{2} \mathrm{O} \rightarrow \mathrm{Ca}_{3}\left(\mathrm{C}_{6} \mathrm{H}_{5} \mathrm{O}_{7}{ }^{3-}\right)_{2}: 4 \mathrm{H}_{2} \mathrm{O}$ & 17.9 & {$[28]$} \\
\hline Ca-Oxalate: $\mathrm{H}_{2} \mathrm{O}$ & $\mathrm{Ca}^{2+}+\mathrm{C}_{2} \mathrm{O}_{4}^{2-}+\mathrm{H}_{2} \mathrm{O} \rightarrow \mathrm{Ca}-\mathrm{C}_{2} \mathrm{O}_{4}: \mathrm{H}_{2} \mathrm{O}$ & 8.73 & {$[28]$} \\
\hline Ca-Oxalate: $2 \mathrm{H}_{2} \mathrm{O}$ & $\mathrm{Ca}^{2+}+\mathrm{C}_{2} \mathrm{O}_{4}{ }^{2-}+2 \mathrm{H}_{2} \mathrm{O} \rightarrow \mathrm{Ca}-\mathrm{C}_{2} \mathrm{O}_{4}: 2 \mathrm{H}_{2} \mathrm{O}$ & 8.30 & {$[28]$} \\
\hline Ca-Oxalate $: 3 \mathrm{H}_{2} \mathrm{O}$ & $\mathrm{Ca}^{2+}+\mathrm{C}_{2} \mathrm{O}_{4}{ }^{2-}+3 \mathrm{H}_{2} \mathrm{O} \rightarrow \mathrm{Ca}-\mathrm{C}_{2} \mathrm{O}_{4}: 3 \mathrm{H}_{2} \mathrm{O}$ & 8.19 & {$[28]$} \\
\hline Ca-Succinate: $3 \mathrm{H}_{2} \mathrm{O}$ & $\mathrm{Ca}^{2+}+\mathrm{C}_{4} \mathrm{H}_{4} \mathrm{O}_{4}{ }^{2-}+3 \mathrm{H}_{2} \mathrm{O} \rightarrow \mathrm{CaC}_{4} \mathrm{H}_{4} \mathrm{O}_{4}: 3 \mathrm{H}_{2} \mathrm{O}$ & $4.4^{(\mathrm{b})}$ & {$[37]$} \\
\hline C-S-H 0.8 & $\begin{array}{l}0.8 \mathrm{Ca}^{2+}+\mathrm{H}_{4} \mathrm{SiO}_{4}+0.34 \mathrm{H}_{2} \mathrm{O} \rightarrow \\
\mathrm{Ca}_{0.8} \mathrm{SiO}_{32.8}(\mathrm{OH})_{0.6}: 1.24 \mathrm{H}_{2} \mathrm{O}+1.6 \mathrm{H}^{+}\end{array}$ & -11.05 & {$[38]$} \\
\hline C-S-H 1.2 & $\begin{array}{l}1.2 \mathrm{Ca}^{2+}+\mathrm{H}_{4} \mathrm{SiO}_{4}+1.26 \mathrm{H}_{2} \mathrm{O} \rightarrow \\
\mathrm{Ca}_{1.2} \mathrm{SiO}_{3.2}(\mathrm{OH})_{1.08}: 1.52 \mathrm{H}_{2} \mathrm{O}+2.4 \mathrm{H}^{+}\end{array}$ & -19.30 & {$[38]$} \\
\hline C-S-H 1.6 & $\begin{array}{l}1.6 \mathrm{Ca}^{2+}+\mathrm{H}_{4} \mathrm{SiO}_{4}+2.18 \mathrm{H}_{2} \mathrm{O} \rightarrow \\
\mathrm{Ca}_{1.6} \mathrm{SiO}_{3.6}(\mathrm{OH})_{1.54}: 1.81 \mathrm{H}_{2} \mathrm{O}+3.2 \mathrm{H}^{+}\end{array}$ & -28.00 & {$[38]$} \\
\hline Ettringite & $\begin{array}{l}6 \mathrm{Ca}^{2+}+2 \mathrm{Al}^{3+}+3 \mathrm{SO}_{4}{ }^{2-}+38 \mathrm{H}_{2} \mathrm{O} \rightarrow \\
\mathrm{Ca}_{6} \mathrm{Al}_{2}\left(\mathrm{SO}_{4}\right)_{3}(\mathrm{OH})_{12}: 26 \mathrm{H}_{2} \mathrm{O}+12 \mathrm{H}^{+}\end{array}$ & -56.97 & {$[38]$} \\
\hline Gibbsite & $\mathrm{Al}^{3+}+3 \mathrm{H}_{2} \mathrm{O} \rightarrow \mathrm{Al}(\mathrm{OH})_{3}+3 \mathrm{H}^{+}$ & -7.74 & {$[38]$} \\
\hline Portlandite & $\mathrm{Ca}^{2+}+2 \mathrm{H}_{2} \mathrm{O} \rightarrow \mathrm{Ca}(\mathrm{OH})_{2}+2 \mathrm{H}^{+}$ & -22.81 & {$[38]$} \\
\hline $\mathrm{SiO}_{2}(\mathrm{am})$ & $\mathrm{H}_{4} \mathrm{SiO}_{4} \rightarrow \mathrm{SiO}_{2}+2 \mathrm{H}_{2} \mathrm{O}$ & 2.71 & {$[26]$} \\
\hline
\end{tabular}

(a) In the case of $\mathrm{Ca}$-(Acetate) $)_{2}$ only, the symbol (s) has been used to discriminate the salt from the aqueous complex; (b) Fitted from experimental solubility.

\section{Table 4.}

Thermodynamic equilibrium constants (mass balance equation) at $25^{\circ} \mathrm{C}$ of aqueous complexation species by inorganics for comparison with Table 2 .

\begin{tabular}{|c|c|c|c|}
\hline Species & Reaction of formation & $\log K$ & Ref. \\
\hline Al-Hydroxyl $^{2+}$ & $\mathrm{Al}^{3+}+\mathrm{OH}^{-} \rightarrow \mathrm{AlOH}^{2+}$ & 9.00 & [25] \\
\hline $\mathrm{Al}-(\text { Hydroxyl })_{2}^{+}$ & $\mathrm{Al}^{3+}+2 \mathrm{OH}^{-} \rightarrow \mathrm{Al}(\mathrm{OH})_{2}^{+}$ & 17.71 & [25] \\
\hline Al-(Hydroxyl) $)_{3}$ & $\mathrm{Al}^{3+}+3 \mathrm{OH}^{-} \rightarrow \mathrm{Al}(\mathrm{OH})_{3}$ & 25.31 & [25] \\
\hline Al-(Hydroxyl $)_{4}^{-}$ & $\mathrm{Al}^{3+}+4 \mathrm{OH}^{-} \rightarrow \mathrm{Al}(\mathrm{OH})_{4}^{-}$ & 33.31 & [25] \\
\hline Ca-Hydroxyl $^{+}$ & $\mathrm{Ca}^{2+}+\mathrm{OH}^{-} \rightarrow \mathrm{CaOH}^{+}$ & 1.30 & [25] \\
\hline Al-Sulphate ${ }^{+}$ & $\mathrm{Al}^{3+}+\mathrm{SO}_{4}{ }^{2-} \rightarrow \mathrm{AlSO}_{4}^{+}$ & 3.81 & [25] \\
\hline Al-(Sulphate $)_{2}^{-}$ & $\mathrm{Al}^{3+}+2 \mathrm{SO}_{4}{ }^{2-} \rightarrow \mathrm{Al}\left(\mathrm{SO}_{4}\right)_{2}^{-}$ & 5.58 & [25] \\
\hline Ca-Sulphate & $\mathrm{Ca}^{2+}+\mathrm{SO}_{4}^{2-} \rightarrow \mathrm{CaSO}_{4}$ & 2.36 & {$[25]$} \\
\hline
\end{tabular}




\section{Table 5.}

Calculated and experimental solubilities of the carboxylic calcium salts.

\begin{tabular}{llll}
\hline Mineral & $\begin{array}{l}\text { Calculated } \\
{[\mathrm{g} / 100 \mathrm{~mL}]}\end{array}$ & $\begin{array}{l}\text { Experimental } \\
{[\mathrm{g} / 100 \mathrm{~mL}]}\end{array}$ & Ref. \\
\hline Ca-(Acetate $)_{2}(\mathrm{~s})$ & $34.7\left(25^{\circ} \mathrm{C}\right)$ & $34.7\left(20^{\circ} \mathrm{C}\right)$ & {$[37]$} \\
$\mathrm{Ca}_{3}-(\text { Citrate })_{2}: 4 \mathrm{H}_{2} \mathrm{O}$ & $0.077\left(25^{\circ} \mathrm{C}\right)$ & $0.096\left(23^{\circ} \mathrm{C}\right)$ & {$[37]$} \\
Ca-Oxalate $: \mathrm{H}_{2} \mathrm{O}$ & $0.0007\left(25^{\circ} \mathrm{C}\right)$ & $0.0007\left(18^{\circ} \mathrm{C}\right)$ & {$[30]$} \\
Ca-Oxalate $2 \mathrm{H}_{2} \mathrm{O}$ & $0.0013\left(25^{\circ} \mathrm{C}\right)$ & $0.0011\left(25^{\circ} \mathrm{C}\right)$ & {$[30]$} \\
Ca-Oxalate: $3 \mathrm{H}_{2} \mathrm{O}$ & $0.0017\left(25^{\circ} \mathrm{C}\right)$ & $0.0013\left(25^{\circ} \mathrm{C}\right)$ & {$[30]$} \\
Ca-Succinate $3 \mathrm{H}_{2} \mathrm{O}$ & $0.41\left(25^{\circ} \mathrm{C}\right)^{(\mathrm{a})}$ & $0.19\left(0^{\circ} \mathrm{C}\right)-$ & {$[37]$} \\
& & $0.89\left(80^{\circ} \mathrm{C}\right)$ & \\
\hline
\end{tabular}

(a) Linear interpolation between the two data. 


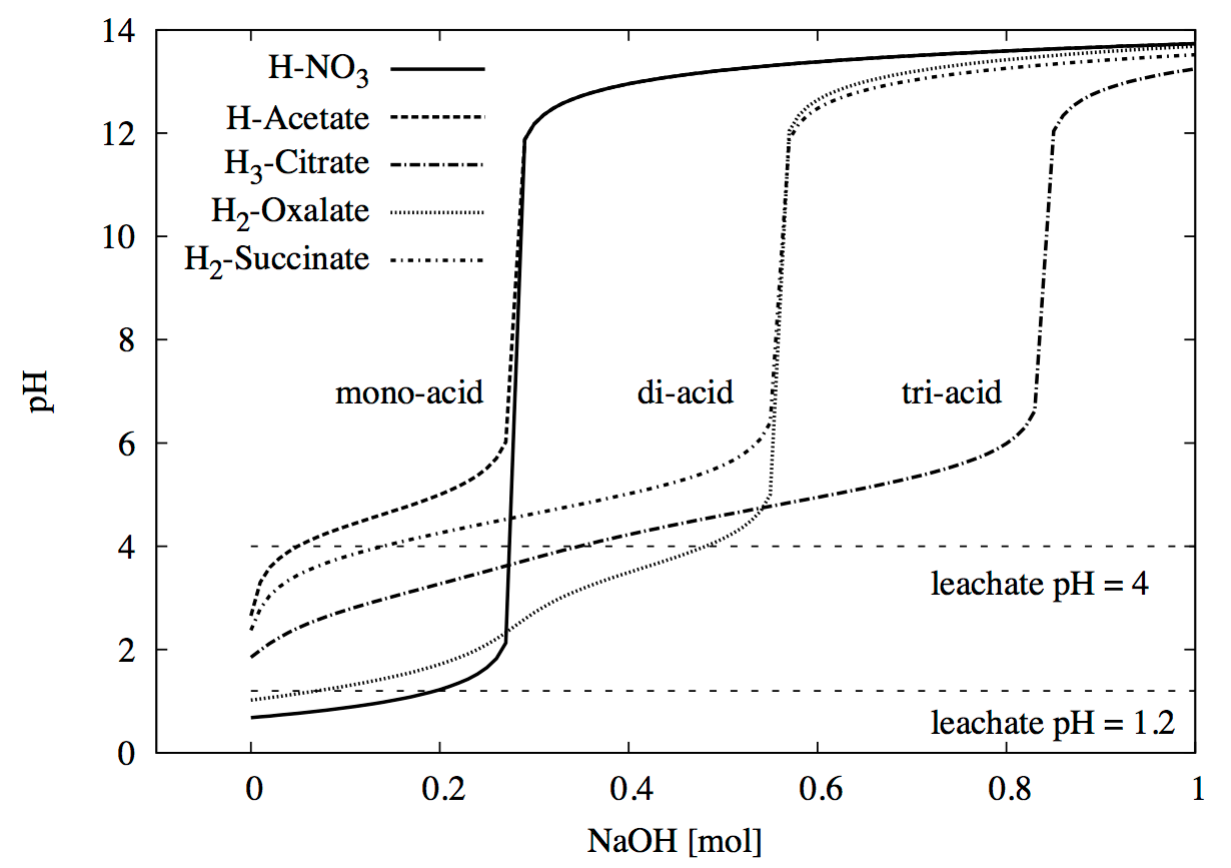

Figure 1. Titration of $280 \mathrm{mmol} / \mathrm{L}$ of each acid by $\mathrm{NaOH}$ demonstrating the poly-acidity properties and relative acid strength. The two horizontal dashed lines correspond to the $\mathrm{pH}$ values buffered in classical leaching experiments with acids.
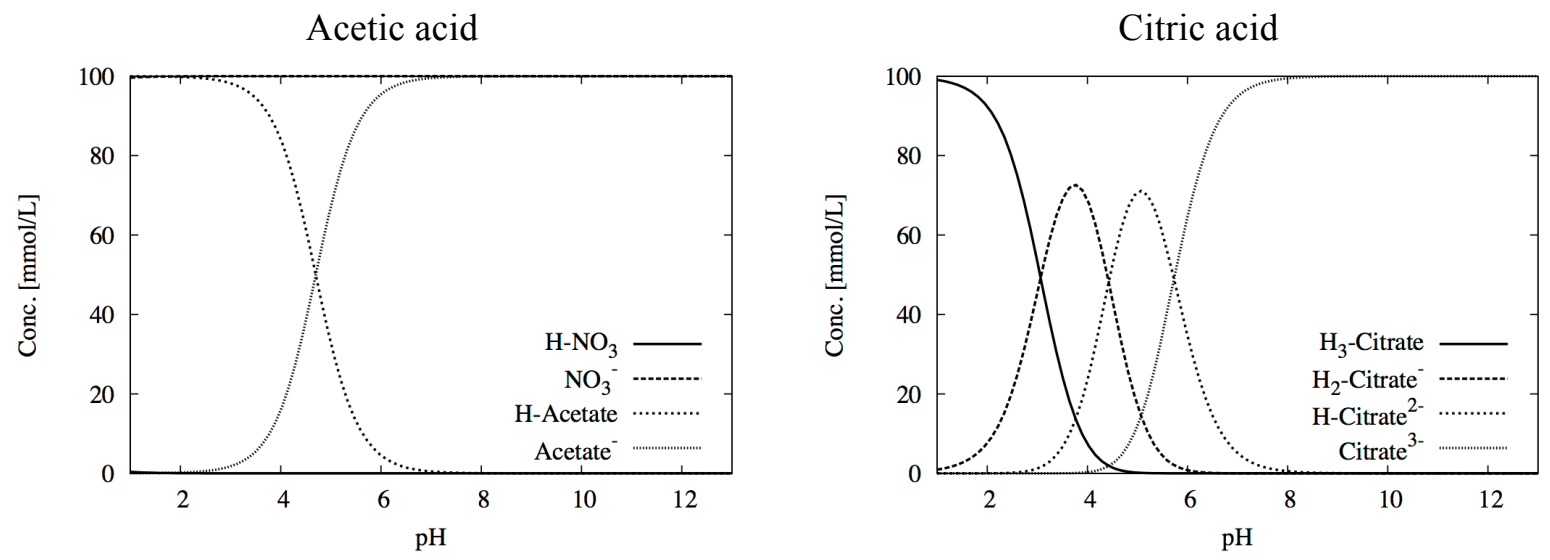

Oxalic acid
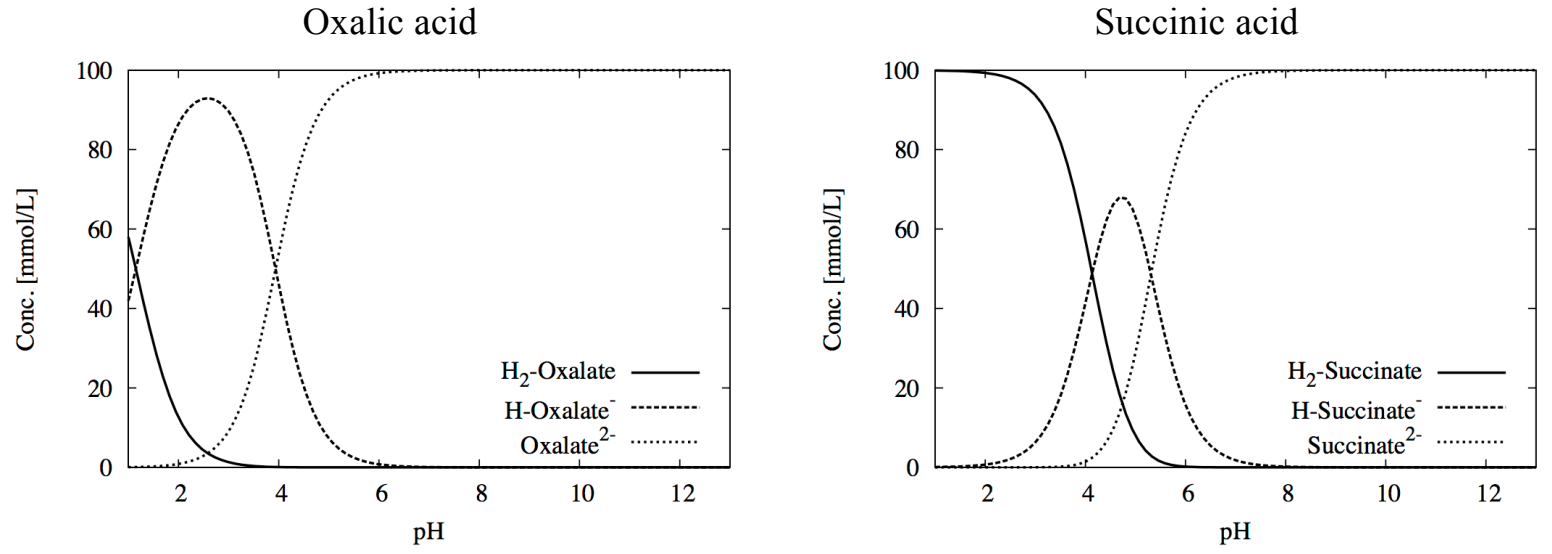

Figure 2. Speciation of the carboxylic acids and their conjugated bases with respect to $\mathrm{pH}$; total aqueous concentration of $100 \mathrm{mmol} / \mathrm{L}$. 

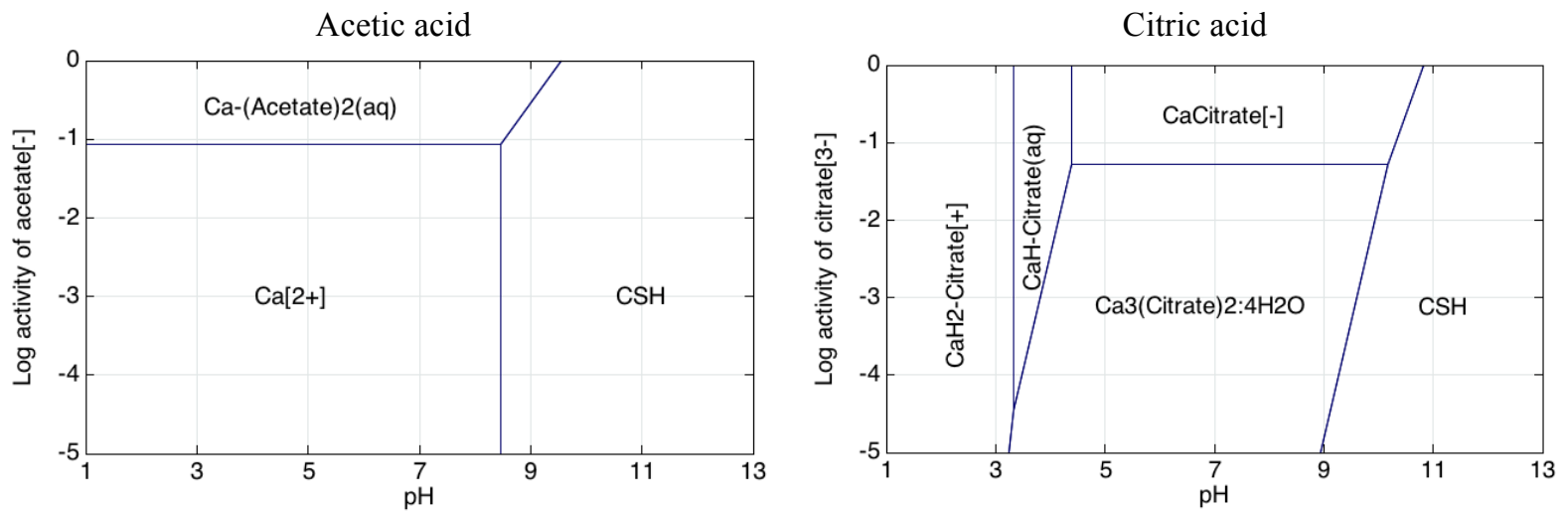

Oxalic acid
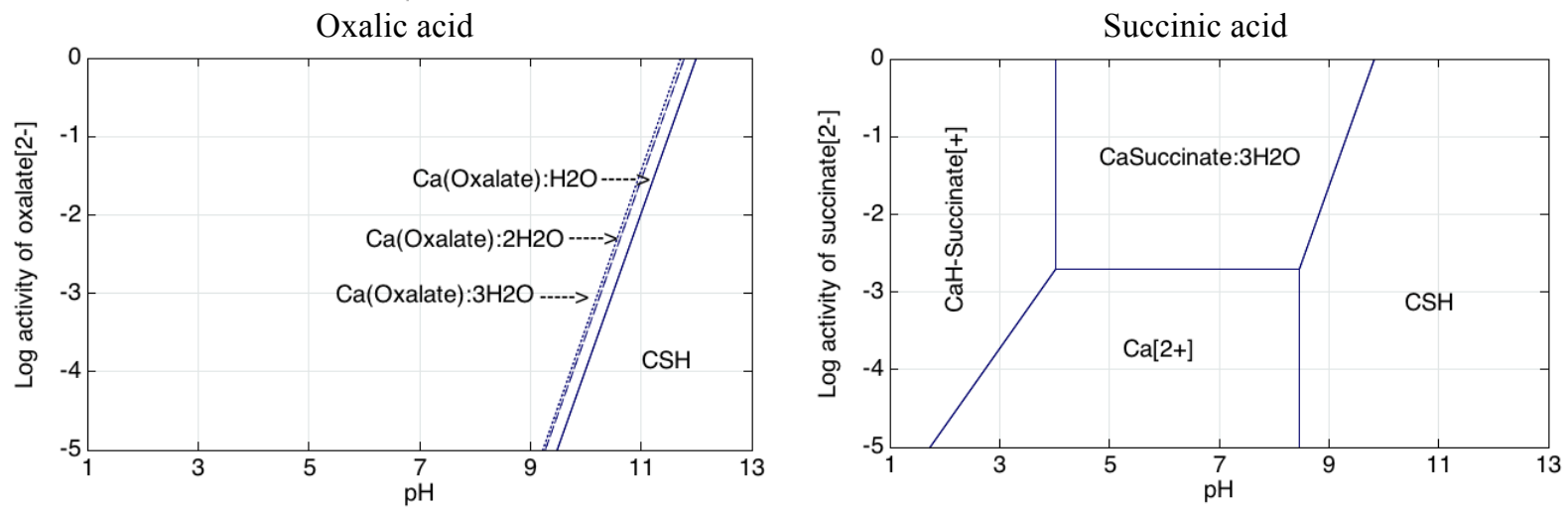

Figure 3. Simplified speciation diagram of calcium - without sulphates - with respect to $\mathrm{pH}$ and the activity of the conjugated bases depicting the boundaries between the aqueous species, the carboxylic calcium salts and cement main phases; total concentrations: $\mathrm{Ca}=20$ mmolal, $\mathrm{H}_{4} \mathrm{SiO}_{4}=$ 100 mmolal. 
Acetic acid

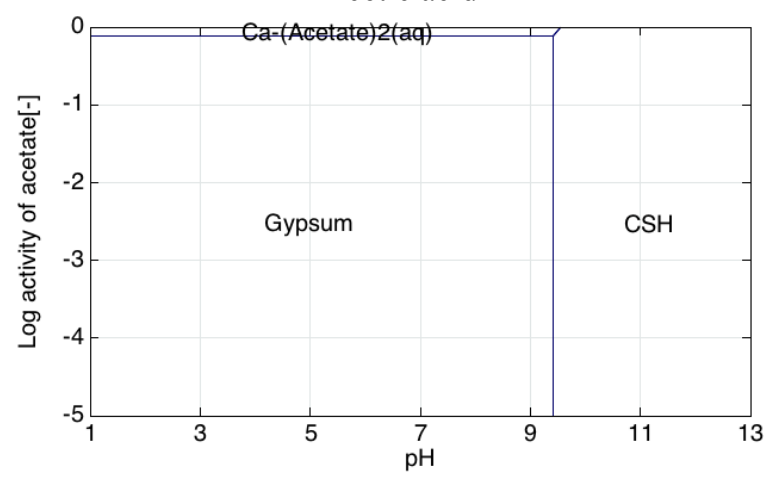

Oxalic acid

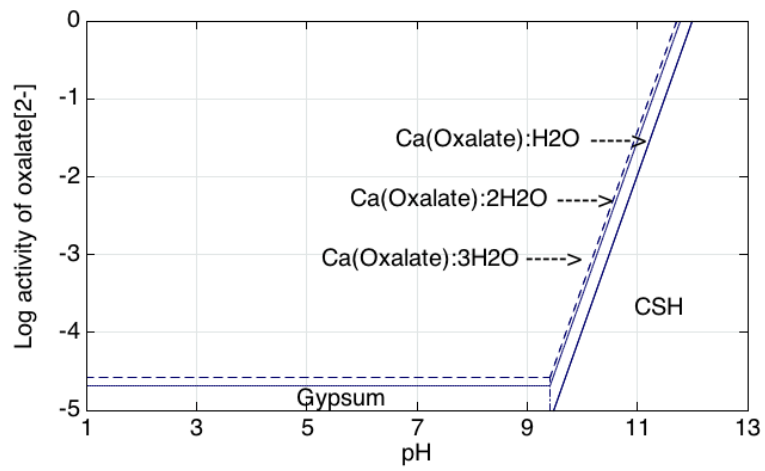

Citric acid

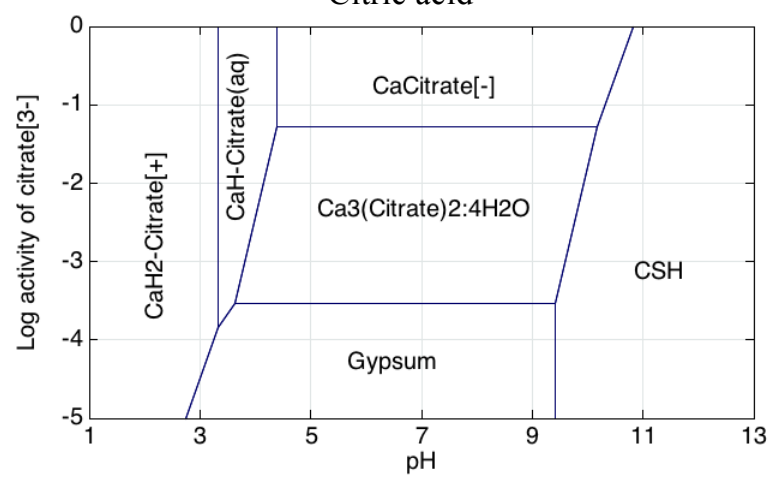

Succinic acid

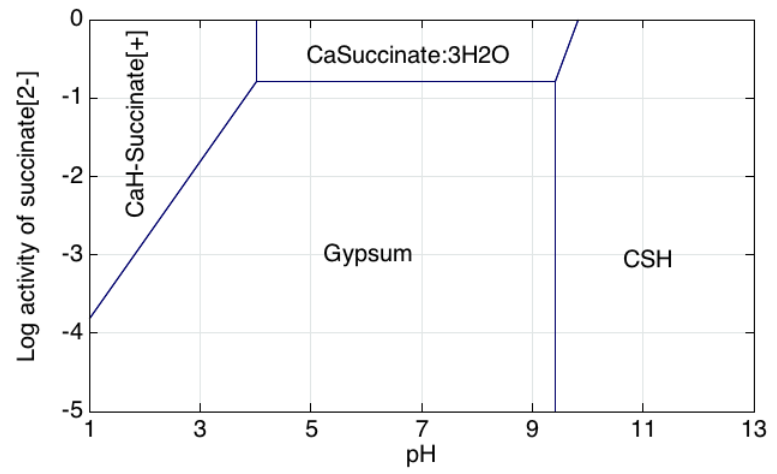

Figure 4. Simplified speciation diagram of calcium - considering sulphates - with respect to $\mathrm{pH}$ and the activity of the conjugated bases depicting the boundaries between the aqueous species, the carboxylic calcium salts and cement main phases; total concentrations: $\mathrm{Al}=0.5 \mathrm{mmolal}, \mathrm{Ca}=20$ mmolal, $\mathrm{H}_{4} \mathrm{SiO}_{4}=\mathrm{SO}_{4}=100$ mmolal. 
Acetic acid

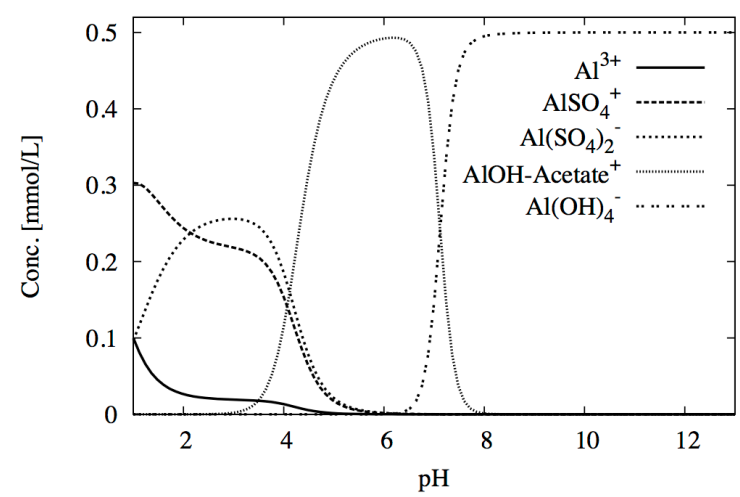

Oxalic acid

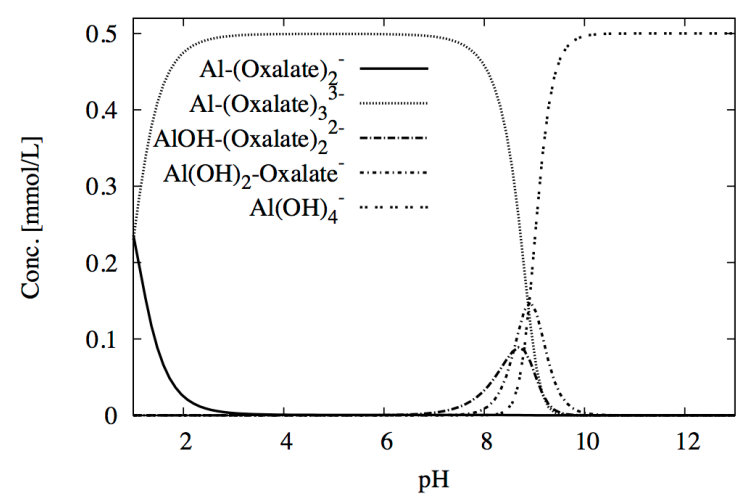

Citric acid

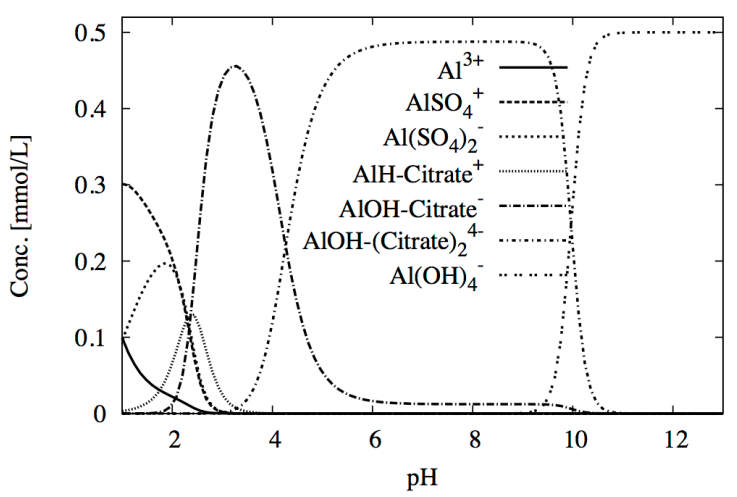

Succinic acid

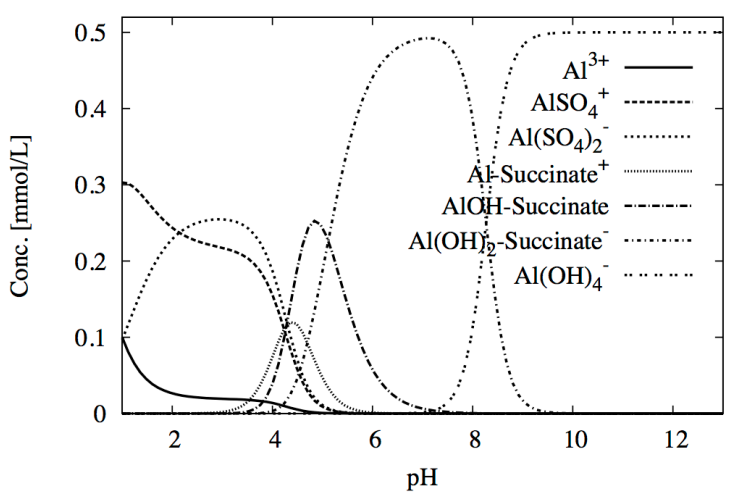

Figure 5. Aluminium speciation - without considering any solids - with respect to $\mathrm{pH}$, discriminating between the different aqueous species; total concentrations: $\mathrm{Al}=0.5 \mathrm{mmol} / \mathrm{L}, \mathrm{Ca}$ $=20 \mathrm{mmol} / \mathrm{L}, \mathrm{Na}_{2} \mathrm{SO}_{4}=$ carboxylic acid $=100 \mathrm{mmol} / \mathrm{L}$. 
Acetic acid

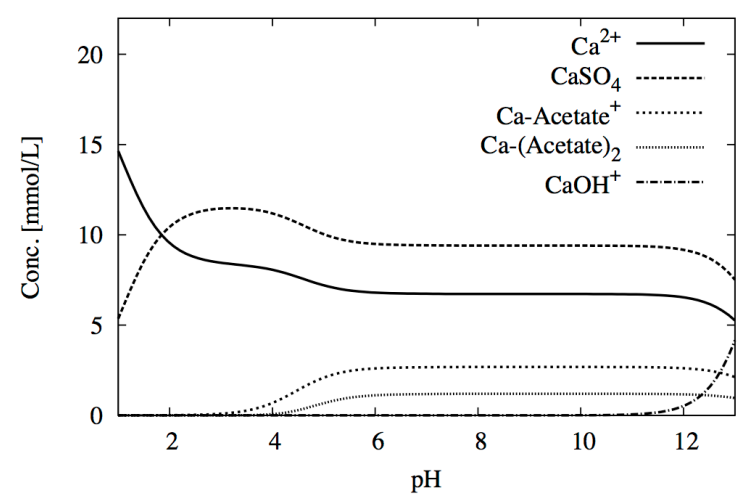

Oxalic acid

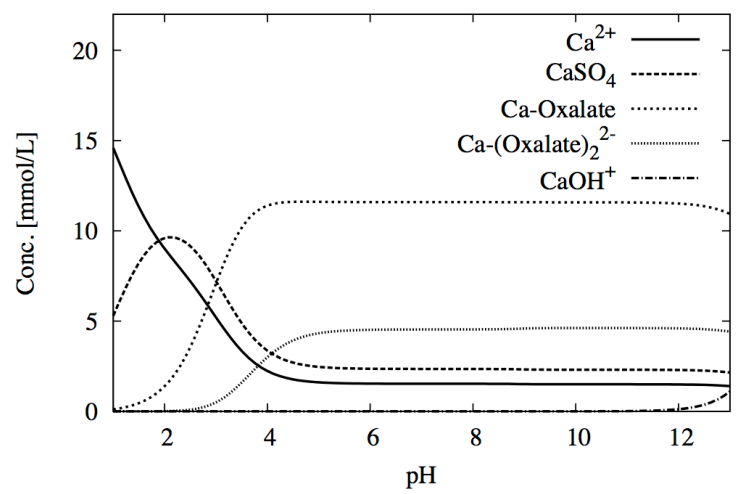

Citric acid

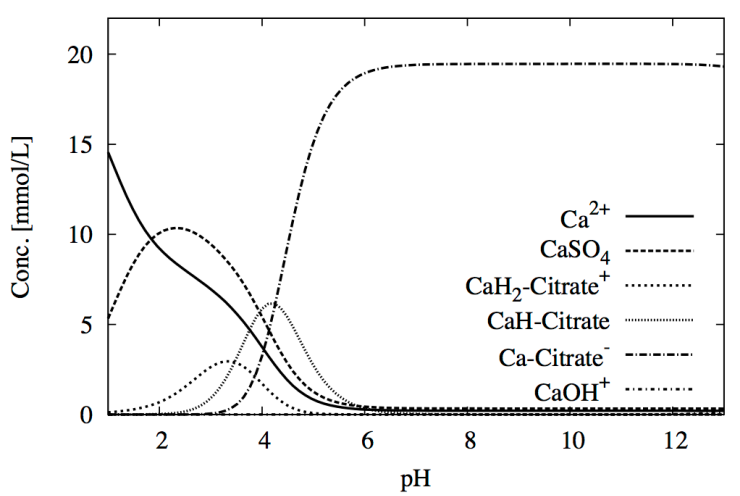

Succinic acid

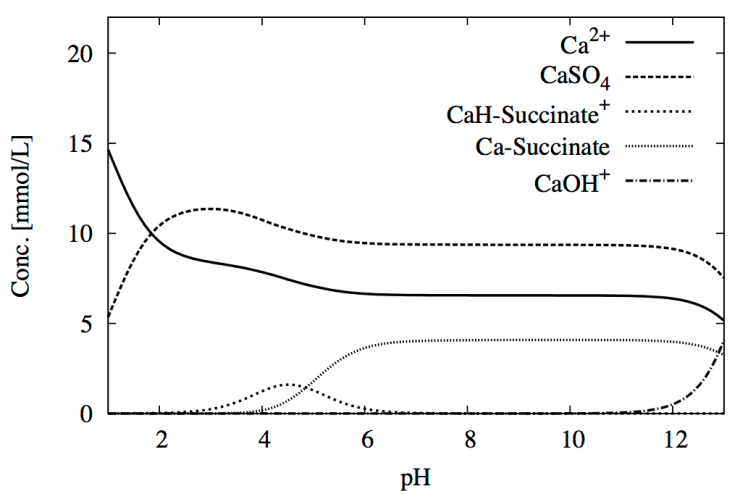

Figure 6. Calcium speciation - without considering any solids - with respect to $\mathrm{pH}$, discriminating between the different aqueous species; total concentrations: $\mathrm{Al}=0.5 \mathrm{mmol} / \mathrm{L}, \mathrm{Ca}$ $=20 \mathrm{mmol} / \mathrm{L}, \mathrm{H}_{4} \mathrm{SiO}_{4}=\mathrm{Na}_{2} \mathrm{SO}_{4}=$ carboxylic acid $=100 \mathrm{mmol} / \mathrm{L}$. 
(A)

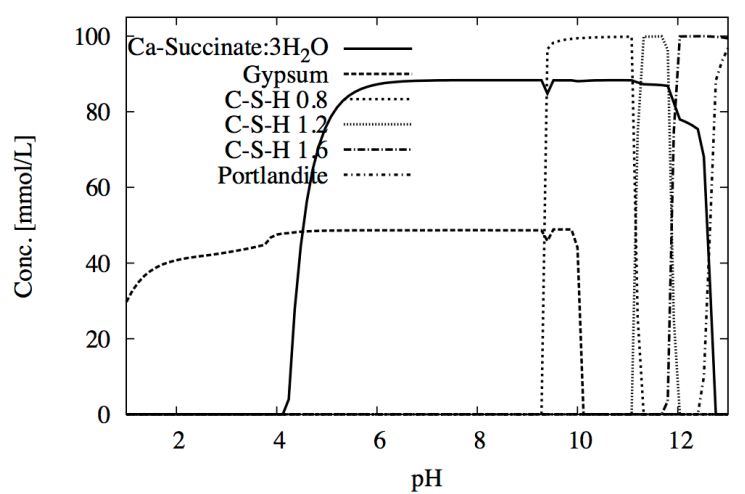

(B)

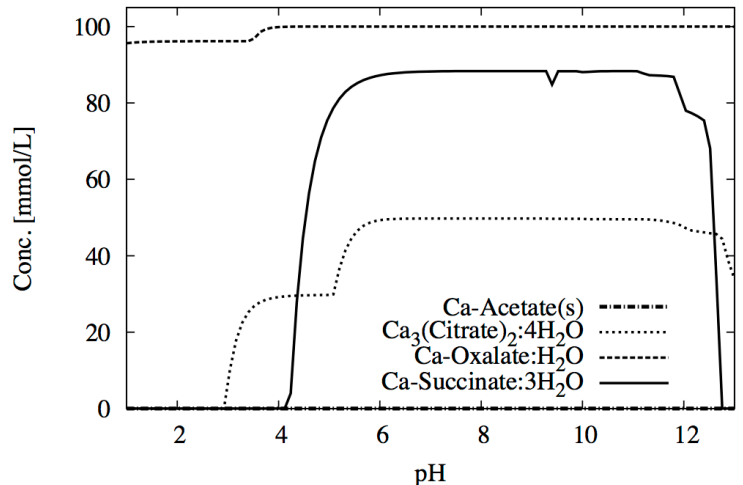

(C)

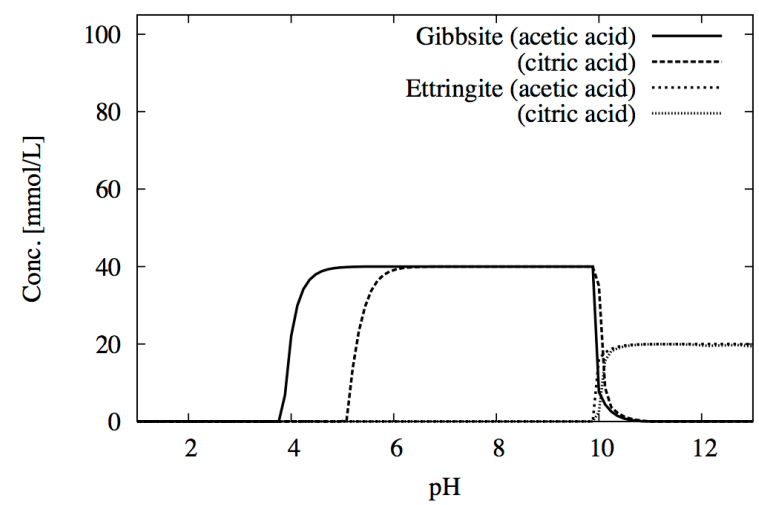

Figure 7. (A) Evolution of calcium solid phases with respect to $\mathrm{pH}$ for a $100 \mathrm{mmol} / \mathrm{L}$ solution of succinic acid. (B) Distribution of calcium salts with respect to $\mathrm{pH}$ for $100 \mathrm{mmol} / \mathrm{L}$ solutions of each carboxylic acids. (C) Evolution of aluminium solid phases with respect to $\mathrm{pH}$ for a 100 $\mathrm{mmol} / \mathrm{L}$ solution of acetic acid or citric acid (the database does not contain any data on $\mathrm{Al}$ acetate salts). In all cases, the concentrations of the initial cement-type hydrates are $\mathrm{C}-\mathrm{S}-\mathrm{H} 1.6=$ portlandite $=100 \mathrm{mmol} / \mathrm{L}$, and ettringite $=20 \mathrm{mmol} / \mathrm{L}$ (see Sec. 5 ). 
(A)

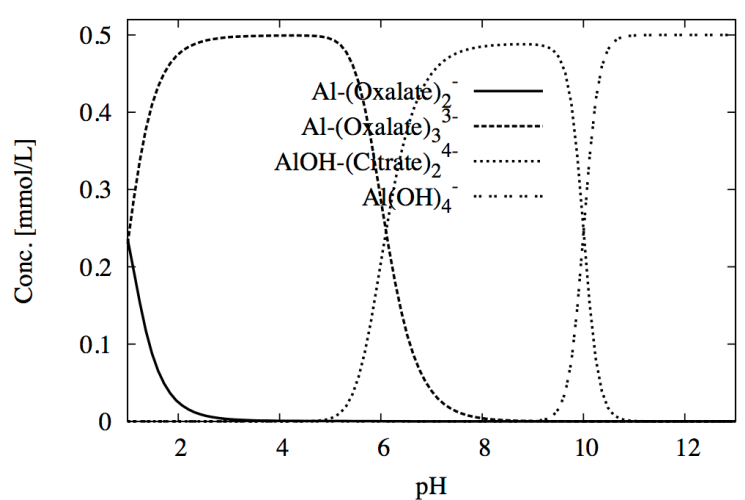

(B)

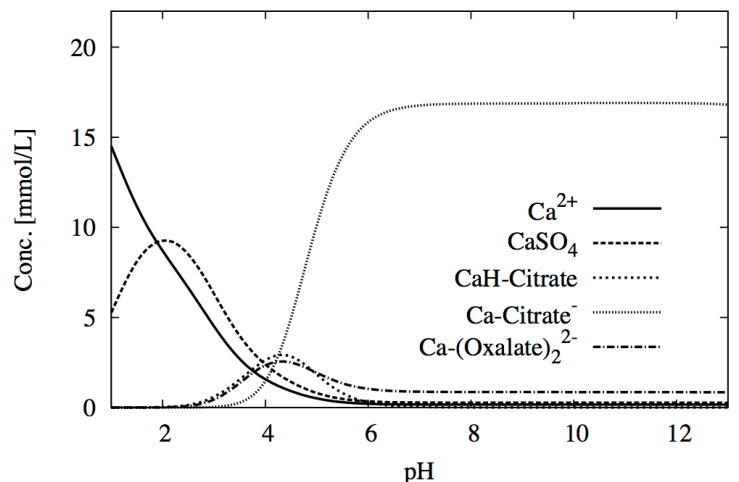

(C)

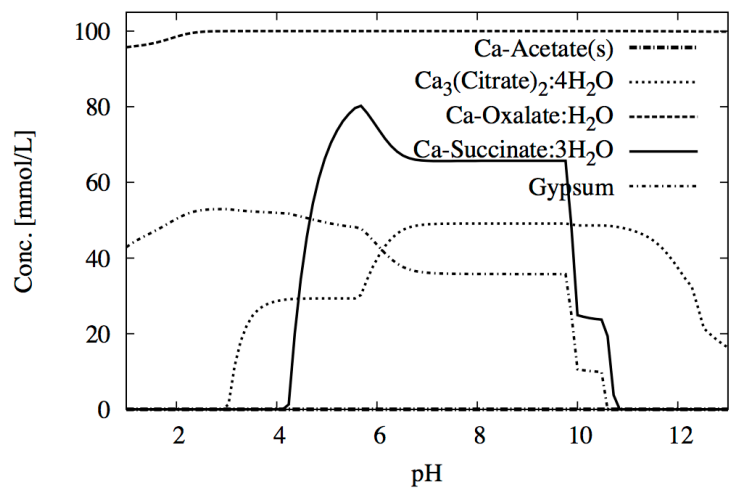

Figure 8. Mixture of the four carboxylic acids for comparison with Figs 5 and 7-B. (A-B) Aluminium and calcium speciation - without considering any solids - with respect to $\mathrm{pH}$ (total concentrations: $\mathrm{Al}=0.5 \mathrm{mmol} / \mathrm{L}, \mathrm{Ca}=20 \mathrm{mmol} / \mathrm{L}, \mathrm{H}_{4} \mathrm{SiO}_{4}=\mathrm{Na}_{2} \mathrm{SO}_{4}=$ acetic $=$ citric $=$ oxalic $=$ succinic $=100 \mathrm{mmol} / \mathrm{L}$ ). (C) Distribution of calcium salts with respect to $\mathrm{pH}$ for the cement-type hydrates in contact with the four-acid solution (aqueous total concentrations: acetic $=$ citric $=$ oxalic $=$ succinic $=100 \mathrm{mmol} / \mathrm{L}$ ). 